\title{
Tıbbi Müdahalelerde Onam Hakkının Sınırı Olarak Üstün Yarar
}

\author{
Özge Yücel ${ }^{*}$ ()
}

Öz

Tıbbi müdahaleler niteliği bakımından kişilik hakkına müdahale oluşturmaktadır ve bu nedenle kişilik hakkını ihlal etmemesi için öncelikle ve kural olarak ilgilinin onamının alınmış olması gereklidir. Tıbbi müdahalede biyoloji ve tıbbın elde ettiği nitelikli bilginin kullanımı sebebiyle onamın hukuka uygunluğu belirli özel koşulları gerekli kılmaktadır, bu koşullardan biri de onamın meşru bir amaca yönelik olarak verilmiş olmasıdır. Öte yandan biyoloji ve tıbba ilişkin özel, nitelikli bilgi toplumsal düzen açısından iktidar sahiplerine tehlikeli bir araç sunmaktadır. Onam yerine geçen hukuka uygunluk sebepleri anayasal ilkeler doğrultusunda yasallık, ölçülülük gibi kriterlere uygun olarak somutlaştırılarak kişilerin bedenleri üzerinde onam alınmaksızın müdahalede bulunulabilmektedir. Söz konusu hukuka uygunluk sebepleri, trbbi müdahaleler söz konusu olduğunda üstün yarar kavramı altında özelleştirilebilmektedir. Onam alınmadan gerçekleştirilecek müdahale ilgilinin kendi yararına veya üçüncü bir kişi yararına olabildiği gibi genel olarak kamunun yararına da olabilir. Ne var ki gerçekte neyin hastalık olduğu veya hangi müdahalenin kime göre nasıl bir yarar sağlayacağı salt bilimsel değil, aynı zamanda politik bir meseledir. illgilinin kendisiyle veya yasal temsilcisiyle çatş̧ma içine düşülerek girişilen tıbbi müdahalelerin meşruluğunun sınırları eleştirel bir yaklaşımla değerlendirilmiştir.

\section{Anahtar Kelimeler}

Özerklik, Psikososyal Varlık, Zorunlu Aşılama, Zorla Tedavi, Organ Bağışı

\section{Superior Interests as a Limitation on the Right to Refuse a Medical Treatment}

\begin{abstract}
Medical interventions constitute an intervention in personal rights in terms of the nature of medical interventions. Therefore, consent of the concerned person should be obtained as a rule to refrain from violating the right to personality. However, the lawfulness of consent requires specific conditions owing to the use of qualified information obtained by biology and medicine in medical intervention. One of such conditions is that consent should be given for a legitimate purpose. Conversely, qualified information obtained by biology and medicine offers decision-makers with a dangerous tool for structuring social order. The reasons for lawfulness replacing consent are embodied in accordance with certain criteria, such as legality and proportionality, in line with constitutional principles. However, in terms of medical interventions, the concept of superior interests may supersede the reasons for compliance with the law. The intervention to be carried out without consent can be either in the interest of a concerned person, a third person, or the public in general. However, which disease or form of intervention will benefit from whom is not only a scientific but also a political issue. Thus, the study critically evaluates the limitations of the legitimacy of medical interventions attempted by engaging in conflict with the person concerned or with a legal representative.
\end{abstract}

\section{Keywords}

Autonomy, Psychosocial Being, Mandatory Vaccination, Mandatory Treatment, Organ Donation

* Sorumlu Yazar: Özge Yücel (Doç. Dr.), Ufuk Üniversitesi, Hukuk Fakültesi, Medeni Hukuk Anabilim Dalı, Ankara, Türkiye. E-posta: ozge.yucel@ufuk.edu.tr ORCID: 0000-0002-6472-0977

Atıf: Yucel O, "Tıbbi Müdahalelerde Onam Hakkının Sınırı Olarak Üstün Yarar" (2021) 79(2) İstanbul Hukuk Mecmuası 441. https://doi.org/10.26650/mecmua.2021.79.2.0003 


\section{Extended Summary}

The values of personality are interrelated, a person's body, mental existence, and social integrity are in constant interaction with one another; consequently, an intervention directed toward one affects the others. Similarly, medical intervention for physiological integrity exerts important effects on the psychosocial existence and integrity of a person. The nature of the method and information used are aspects that characterize intervention to personality values as medical intervention rather than the objective of the intervention or who conducts the intervention.

In general, a person exposed to an intervention using medical information is situated in a weak position owing to the lack of this information. Moreover, the fact that the relationship established with a patient or a counselee is at risk of exploitation is also based on this asymmetry. Such qualified information not only leads to the establishment of a hierarchical relationship but also is instrumentalized by the ruling owner for the continuity of order. Furthermore, obedience from individuals is transformed into a tool of social control over bodies through various arguments and medicine. Thus, the present study highlights the effects of social control motivation on the condition of usefulness in medical interventions from the viewpoint of biopolitics.

When the conditions of the lawfulness of consent are reviewed using the aforementioned approach, interventions should not be considered necessary for health or beneficial in terms of health welfare. However, they should be oriented toward a legitimate purpose. When such interventions are declared necessary or beneficial for health in line with subjective evaluations, an unjustified restriction can be imposed on the right of individuals to determine their relations, body, and future. In other words, a certain lifestyle can be imposed on individuals. Moreover, it recommendations within interventions may change over time in terms of the nature of the disease and, therefore, cases that require medical intervention. Notably, medicine is extremely political, especially in terms of mental illnesses.

Although the concept of superior interests is arguably the mainstay of all medical interventions without consent, no real conflict exists in terms of the will of the person in terms of medical interventions for personal interests based on the assumed consent. This study discusses the legitimacy of medical interventions conducted without consent of the person or their legal representative. Moreover, distinguishing the criteria regarding conflict with legal representatives as discussed herein is necessary. However, legal representatives are not entitled to evaluate and make decisions arbitrarily because they make decisions for another person's body and not theirs. The sole purpose of the powers granted to legal representatives is to protect the interests of mentally incapable persons, to allow the necessary interventions, and to prevent 
unnecessary interventions. At this point, if the mentally incapable person that requires intervention does not resist, refuse, and, therefore, does not engage in conflict, then the interests of the said person have decisive importance instead of the opinion of the legal representative. In this respect, the study discusses vaccines for infants and differentiates them from mandatory vaccines intended for adults. By contrast, in a situation where a competent person who is undergoing medical intervention is engaged in a conflict with him the legal representative, whether the consequences that may occur owing to the lack of intervention will damage the state power or the fundamental rights and freedoms of others should be examined. The rationale for preserving an abstract state power frequently does not serve other interests apart from disciplining people and obtaining their obedience.

If the benefits provided by an intervention are considerably nonsignificant in the face of the burdens that the intervention creates for the individual in the case of violation of autonomy, intervention should be avoided because it cannot be regarded with proportionality as per the Constitution. One of the aspects that must change is the regulation that envisages forced examination for victims of sexual violence because the compulsion of the victims will create secondary trauma and will lead to continued violence. Alternatively, the present study emphasizes that exceptions should not be made for the avoidance of intervention without consent. This condition applies to biological substance donation and experiments for scientific purposes only owing to the lack of moral justification for expecting an individual to make sacrifices despite the fact that the conditions of the person do not create a burden for society. 


\section{Tıbbi Müdahalelerde Onam Hakkının Sınırı Olarak Üstün Yarar}

\section{Giriş}

Kişilik hakkının koruma alanı içinde bulunan kişilik değerlerinin başında gelen beden bütünlüğüne yönelik müdahaleler arasında tıbbi müdahaleler hukuksal sonuçları bakımından özel bir öneme sahiptir. Tıbbi müdahalelerin hukuka uygun olabilmesinin temel koşulu ilgili kişinin onamının alınmış olması veya onamın yerine geçebilen bir hukuka uygunluk sebebinin bulunmasıdır. Onamın yerine geçebilen hukuka uygunluk sebebinin kişinin özerklik hakkının etkisiz hale getirilmemesi gereği dikkate alındığında istisnai bir nitelik taşıdığı açıktır. Anayasada beden bütünlüğünün dokunulmazlığı bağlamında onam yerine geçen sebeplerin açıkça öngörülmediği, buna karşılık Türk Medeni Kanunu'nda üstün yarar kavramıyla soyut bir sınırlandırma sebebi öngörüldüğü dikkat çekmektedir. İlgilinin onamı alınmaksızın girişilen tıbbi müdahalelerde hukuka uygunluk sebebi olarak gösterilen üstün yarar kavramı, ilgili kişinin kendi yararıyla veya başkasının veya kamu yararıyla ilişkilendirilebilmektedir.

Çalışmada doğrudan doğruya onam vermesi gereken kişiyle çatışma içine düşülen durumlar inceleme konusu yapılmış olup onam vermesi gereken ilgili kişinin bilinci yerinde olmadığg için ve varsa yasal temsilcisine de ulaşılamadığ 1 için onun muhtemel iradesine veya objektif olarak tasavvur edilen varsayılan iradesine uygun olarak girişilen tıbbi müdahalelerde bir çatışma, çekişme ortaya çıkmadığı için bu tür tıbbi müdahalelerdeki üstün yarar kavramı incelemenin dışında bırakılmıştır. Söz konusu çatışma ile ehliyetli bir kişinin iradesine aykırı olarak girişilen müdahaleler yanında ayırt etme gücünden yoksun kişinin yasal temsilcinin iradesine aykırı olarak girişilen müdahalelerde ve ayırt etme gücünden yoksun kişinin doğal iradesine aykırı şekilde gönülsüz, zorla girişilen müdahalelerde de karşılaşılmaktadır. İlgilinin kendisiyle veya yasal temsilcisiyle çatışma, çekişme içine düşülerek girişilen tıbbi müdahalelerin meşruluğu yasal düzenlemelere biyopsikososyal yaklaşım çerçevesinde eleştirel biçimde değerlendirilecektir.

\section{Tıbbi Müdahalelerde Onam Hakkının Temelleri ve Sınırları}

\section{A. Biyopsikososyal Yaklaşımla Tıbbi Müdahale Kavramı}

Tıbbi müdahale kavramının öğretide çeşitli tanımları bulunmaktadır. ${ }^{1}$ Söz konusu tanımlarda ortak olan husus insan bedenine yönelik tıbbi amaçlarla veya yöntemlerle 
müdahalede bulunulmasıdır. ${ }^{2}$ Öncelikle belirtmek gerekir ki kişinin kendi bedenine yönelik eylemleri acı verici de olsa müdahale anlamına gelmeyecektir, bu nedenle bir başkasının etkisi olmaksızın kişinin kendi kararıyla kendi bedenine yönelik eylemleri, bir hukuksal işleme konu olmadıkça, kural olarak hukukun düzenleme alanında değildir. ${ }^{3}$ Dolayısıyla müdahale ile kast edilen, bir kimsenin doğrudan veya dolaylı olarak bir başkasının bütünlüğüne, varlığına etkide bulunulmasıdır. ${ }^{4}$ Tıbbi müdahale tanımlarında sözü edilen "insan bedeni" unsuru iki açıdan sorunludur.

Beden ile kast edilenin genellikle ruhsal yaşamı değil, organ, doku, kemik, kas gibi unsurlardan oluşan anatomik yapı olduğu anlaşılmaktadır. Oysaki kişiliğe müdahale birinin hem maddi varlığına hem de manevi varlığına etkide bulunmaya elverişli eylemleri ifade eder. ${ }^{5} \mathrm{Bu}$ noktada bireyin psikolojik varlığını sosyal varlığından ayrı tutmak anlamlı değildir. Erikson'un psikososyal gelişim kuramında ileri sürüldüğü üzere insanların gelişimi çevresindekilerle ilişkilerine, sosyal dinamiklere dayanmaktadır. ${ }^{6}$ Bireyin psikolojik varlığının çevresindekilerle ilişkileri ile, bir başka ifadeyle sosyal varlığ 1 ile etkileşimi yalnızca bireyin gelişimi aşamasında değil yaşamı boyunca kendini göstermektedir. ${ }^{7}$ Psikososyal yaklaşımın iş ortamı, yoksulluk, şiddet gibi sosyal koşullardan hareketle stres üreten ve sonuçta biyolojiyi ve böylece fiziksel ve zihinsel rahatsızlıkları etkileyen öznel deneyimlere odaklandığı belirtilmektedir. ${ }^{8}$ Dünya Sağlık Örgütü'nün sağlığı bedensel, ruhsal ve sosyal açıdan tam iyilik hali olarak açıklamasının temelinde de bu etkileşimin bulunduğu ileri sürülebilir. Bu açıdan tıbbi müdahalenin de kişinin hem bedenine hem de ruhsal (psiko)-sosyal varlı̆̆ına yönelik müdahaleleri kapsar şekilde anlaşılması gerekmektedir. ${ }^{9}$ Kuşku yoktur ki bedene yönelik müdahaleler kişinin psikososyal varlığını, psikososyal varlığına

\footnotetext{
Öğretide tıbbi müdahale kavramı ile bunun hukuka uygunluk koşullarının özdeşleştirilerek tanım yapıldığı dikkat çekmektedir. Bakınız Kirkit (n 1) 15-17; Badur (n 1) 36, 41.

Bunun tek istisnası gebe kadının belirli bir gebelik süresinden sonra gebeliğini sonlandırmasının suç oluşturmasıdır. Bunun temelinde ceninin beklenen yaşam menfaatinin kadının bedensel özerkliği menfaatinden üstün tutulması düşüncesi vardır. Buna karşılık kiş̧inin kendine vereceği zarar ölümcül olsa dahi herhangi bir yaptırım sebebi oluşturmaz. Fakat kişinin kendine zarar verme eğilimi onun tıbbi tanı alarak hasta sayılmasına ve böylece tıbbın normlarına göre disiplin altına alınmasına yol açabilmektedir.

4 Seda Kara Kılıçarslan, Kişilik Hakkına Saldırıda Üstün Nitelikte Özel ve Kamusal Yarar (On İki Levha 2015) 12-13.

5 Oğuzman, Seliçi ve Oktay-Özdemir, beden bütünlüğüne kişinin hem fiziksel hem ruhsal değerlerinin dahil olduğunu belirtmektedir. Kemal Oğuzman, Özer Seliçi ve Saibe Oktay-Özdemir, Kişiler Hukuku (Gerçek ve Tüzel Kişiler) (19. Bası, Filiz 2020) 178.

6 Gabriel A Orenstein ve Lindsay Lewis, 'Eriksons Stages of Psychosocial Development' (StatPearls, 9 March 2020) Treasure Island (FL): StatPearls Publishing <https://www.ncbi.nlm.nih.gov/books/NBK556096/> Erişim Tarihi 9 Haziran 2020; Sage Rose ve Cecil Robinson, 'Beyond Essentialist Critiques: The Co-development of Individual and Society within Erik Erikson's Psychosocial Theory of Identity Development' iç SA Barab, KE Hay ve DT Hickey (edr), The International Conference of the Learning Sciences, Indiana University, Proceedings of ICLS 2006, Vol 2 (International Society of the Learning Sciences 2006) 621 vd; Lynn Froggett ve Barry Richards, 'Exploring the Bio-Psycho-Social' (2002) 5(3) The European Journal of Psychotherapy, Counselling \& Health 321, 322-326.

Orenstein ve Lewis (n 6).

8 Michael Marmot, 'Giriș' iç Michael Marmot ve Richard G Wilkinson (edr), Sağlığın Sosyal Belirleyicileri, Çeviri Editörleri İlker Kayı ve Yeşim Yasin (İnsev 2009) 15-16; Michael Marmot, Johannes Siegrist ve Tores Theorell, 'Sağlık ve İş Yerindeki Psiko-Sosyal Ortam' iç Michael Marmot ve Richard G Wilkinson (edr), Să̆lığın Sosyal Belirleyicileri, Çeviri Editörleri İlker Kayı ve Yeşim Yasin (İnsev 2009) 119, 136-137. Ayrıca bakınız Mustafa Çalışkan, Madde Bağımlılığının Biyo-PsikoSosyal ve Hukuksal Analizi (Beta 2018) 16-18, 31.

9 Madde bağımlılığına ilişkin olarak psikososyal tedaviler hakkında bakınız Çalışkan (n 8) 189 vd
} 
yönelik müdahaleler de kişinin bedenini etkilemektedir. ${ }^{10}$ Ancak burada doğrudan doğruya etkide bulunulması hedeflenen varlık doğrultusunda ayrım yapılmaktadır. Hakaret veya cinsel saldırı kişinin psikososyal varlığına yönelik müdahalelerdendir ve haksızdır. ${ }^{11}$ Eğitim veya sanat faaliyeti de kişinin psikososyal varlığına yönelik müdahalelerdendir ve haklı ya da haksız olması amacı, onama dayanıp dayanmadı $\breve{g}$, yöntemi gibi farklı bileşenlere bağlıdır.

Tıbbi müdahaleyi diğer müdahalelerden ayırt eden şey bunun yol açabileceği sonuçlardan ziyade hangi yöntemle gerçekleştirildiğidir. ${ }^{12}$ Zira tıbbi müdahaleden ilgilinin zarar görmesi de yarar sağlaması da mümkündür. Öte yandan tıbbi müdahalelerin kapsamı yararlı sonucun amaçlanmasından ibaret görülemez, o kişiye zarar verme kastıyla yapılacak bir ameliyat da tıbbi müdahaledir ve hukuka aykırıdır. Öyleyse müdahaleyi "tıbbi" müdahale kılan, hangi yöntemle gerçekleştirildiğidir. Tıp ve biyoloji biliminin elde ettiği özel bilgilere dayanan yöntemler müdahaleleri nitelikli kılmaktadır. Geleneksel yaklaşım çerçevesinde tıbbi müdahale kavramının tıbbi gereklilik sebebiyle girişilen müdahalelerle sınırlandırılmasının temelinde biyopolitikayı görünmez kılma saikinin etkili olduğu ileri sürülebilir. Bilimsel bilgi ve teknolojiye dayanan söz konusu nitelikli yöntemler tıp ve biyolojiyi araçsallaştırma riskini beraberinde getirmektedir. ${ }^{13}$ Sağlik alanında lisans eğitimi bulunmayan bir kişinin herhangi bir bitkinin tüketiminin canlı sağlığında yol açabileceği etkileri bilmesi veya bir kişinin nasıl ameliyat edileceğini bilmesi mümkün değildir, söz konusu bilgi asimetrisi tıbbın ve biyolojinin biyopolitika ${ }^{14}$ için güçlü bir silaha dönüşmesine yol açmaktadır. Foucault biyopolitikayı şöyle açıklamaktadır: “... yönetim pratiğinin nüfusu oluşturan canlıların karşılaştığı sorunları (să̆llk, hijyen, doğum oranı, yaşam süresi, ırklar...) akılsallaştırma çabası". ${ }^{15}$ Örnek vermek gerekirse bir kişinin ne kadar alkol kullandığı salt genel gözlemle belirlenemez, tahmin edilebilir, oysaki tıbbi teknoloji sayesinde yüzdeyle ifade edilecek kadar

10 Bakınız Marmot, Siegrist ve Theorell (n 8) 136-137.

11 Psikososyal varlığa yönelen ani saldırılar veya müdahaleler yanında kronikleșen müdahaleler de sağlığı etkilemektedir. Bu bağlamda farklı sebeplerle damgalanma ve ötekileştirme suretiyle toplumsal dışlanmanın etkilerine değinilmektedir. Bakınız Mary Shaw, Danny Dorling ve George Davey Smith, 'Yoksulluk, Toplumsal Dışlanma ve Azınlıklar' iç Michael Marmot ve Richard G Wilkinson (edr), Sağlığın Sosyal Belirleyicileri, Çeviri Editörleri İlker Kayı ve Yeşim Yasin (İnsev 2009) 239

12 Aynı yönde bakınız Burcu Ertem, Tıp Ceza Hukukunda Kendi Geleceğini Tayin Hakkının Yansıması Olarak Rıza ve Sinırları, Yayımlanmamış Doktora Tezi (Ankara Üniversitesi Sosyal Bilimler Enstitüsü 2015) 25-27.

13 Aynı yönde bakınız Ertem (n 12) 25-27. Öğretide Foucault'nun tıbbı (ilaçları) biyopolitik bir strateji olarak nitelendirdiği belirtilmektedir. Bakınız Altuğ Koç, 'Michel Foucault'nun 'Biyopolitika' Kavramının Teorik Çerçevesi' (2018) 2(2) Uluslararası Kriz ve Siyaset Araştırmaları Dergisi 193, 195; Sevtap Metin, Biyo-Tıp Etiği ve Hukuk (2. Bası, Betim 2019) 471 vd; Nagehan Gürbüz, Biyotıp Hukukunda İnsan Onuru (On İki Levha 2014) 359. Biyoteknoloji kavramı hakkında ayrıntılı açılamalar için bakınız Burcu Kalkan Oğuztürk, Türk Medeni Hukukunda Biyoetik Sorunlar (Vedat 2011) 88 vd

14 Bedenin iktidarın nesnesi ve hedefi olduğu teziyle açıklanan biyopolitika kavramı Foucault’ya dayanmaktadır. Michel Foucault, Hapishanenin Doğuşu Çeviren Mehmet Ali Kılıçbay (8. Bası, İmge 2019) 209-211. Foucault'nun Hapishanenin Doğuşu ve Biyopolitikanın Doğuşu, Deliliğin Tarihi adlı eserlerinde açıklandığı üzere okullar, asker kışlaları, hapishaneler, akıl hastaneleri gibi etrafı çevrilen, kișilerin kapatıldıkları kurumlar insanları disiplin altına almaya yöneliktir. Bakınız Michel Foucault, Biyopolitikanın Doğuşu Collége de France Dersleri 1978-1979 Çeviren Alican Tayla (İstanbul Bilgi Üniversitesi 2015) 31-32, 57-58; Foucault, Hapishanenin Doğuşu (n 14) 207-224, 303, 309-311.

15 Foucault, Biyopolitikanın Doğuşu (n 14) 263. 
kesinlikte olmak üzere kişinin kanındaki alkol tespit edilebilmektedir. ${ }^{16}$ Bir başka örnek vermek gerekirse uyuşturucu madde satıcısının yakalanmamak için bunu yutması halinde uyuşturucunun bedenden çıkarılması veya bedendeki varlığının tespiti için başvurulan nazogastrik yöntemler buna işarettir. ${ }^{17}$ Bir başka açıdan genetik tanı yöntemleriyle istenilen özellikleri taşımak üzere üremeye başvurulması veya isteğe bağlı kürtaja izin verilmeyen ülkelerde genetik anomalinin varlığı halinde kürtaja izin verilmesi de biyopolitikayla doğrudan ilişkilidir. Nazi döneminde engelli olduğu tespit edilen kişilerin yaşamına toplu şekilde son verilerek hasta olmayan urk yaratma hedefi yönünden de tıbbi bilginin araçsallaştırıldığı açıktır. ${ }^{18}$ Benzer şekilde cinsiyet kimliği, cinsel yönelimi, sosyoekonomik statüsü (dilencilik yapan yoksullar gibi) veya muhalif görüşleri sebebiyle "öteki” görülen ve damgalanan insanların geçmişte psikiyatri tarafından hastalık tanısıyla hastanelere kapatılması halinde de tıp araçsallaştırılmaktadır. ${ }^{19} \mathrm{Bu}$ tür müdahalelerin pek çoğunun tıbbi müdahale kavramının dışında tutulmaya çalışılması anlamlıdır, bu yaklaşım aracılığıyla tıbbi müdahalelere özgü hukuka uygunluk koşullarının bu müdahalelerde aranmasının gerekli olmadığı izlenimi uyandırılabilmektedir. Oysaki ister tıbbi gereklilik nedeniyle ister başka amaçlarla olsun tüm tıbbi müdahaleler için hukuka uygunluk koşullarının varlığının tartışılması gereklidir.

Tıbbi müdahalenin salt insan ile ilişkilendirilmesi ve diğer canlılar üzerinde biyoloji ve tıbbın uygulanmasının tıbbi müdahale literatürüne dahil edilmemesi dikkate değerdir. Oysaki insanlar üzerinde uygulanan tedavi yöntemleri çoğu kez öncelikle insan dışı deney ortamında, özellikle hayvanlar üzerinde denenmektedir. Çünkü tıbbi yöntemlerin hayvanlar üzerinde de etkili olduğu, hayvanların da hem bedenini hem de psikolojisini etkilediği bilinmektedir. Ne var ki biyopolitikanın hayvanları bugünkü normatif düzende özne saymaktan uzak olması ile hayvanların bedensel ve psikolojik varlı̆̆ını etkileyen müdahalelerin ve veteriner hekimliğin 1219 sayılı Tababet ve Şuabatı Sanatlarının Tarzı İcrasına Dair Kanunda hiçbir şekilde yer almaması rastlantı değildir. Hayvan üzerindeki deneyler ile insan üzerinde deneylerin hukuka uygunluk koşulları arasında önemli farklılıklar vardır, bu farklılıklar salt hayvanın kendi iradesini yönetebilen ve ifade edemeyen bir varlık

16 Hakan Kizılarslan, Ceza Muhakemesi, Adli Tip, Adli Bilimlerde Vücut Muayenesi ve Örnek Alma (Doktrin ve Uygulama) (Kizılarslan 2007) 160-161.

17 Bakınız Jalloh v Germany App no 54810/00 (ECHR, 11 July 2006) <http://hudoc.echr.coe.int/eng?i=001-76307> Erişim Tarihi 5 Temmuz 2020.

18 Nazi döneminde deneyler aracılığıyla tıbbın politik bir araç olarak kullanımı hakkında Bakınız Gökberk Dumancı, İnsan Konulu Klinik Araştırmalar ve Hukuki Boyutu (Legal 2020) 11-15.

19 Bakınız Foucault, Biyopolitikanın Doğuşu (n 14) 31; Thomas Szasz, Deliliğin İmalatı Çeviren Gözde Genç (Yerdeniz 2007) 319; Michel Foucault, Akıl ve Akıl Bozukluğu Klasik Çă̆da Deliliğin Tarihi Çeviren Mehmet Ali Kılıçbay (2. Bası, İmge 1995) 723 vd. Foucault, tıbbın zihinsel patolojisi bulunan kişiler yönünden sosyal bir tedbir amacıyla stratejik biçimde kullanıldığına, bugün eziyet olarak nitelendirilebilecek bazı yöntemlere o kişileri kontrol altında tutabilmek ve islah edebilmek amacıyla başvurulduğuna ișaret etmektedir. Bakınız Michel Foucault, Akıl Hastalığl ve Psikoloji Çeviren Emre Bayoğlu (5. Bası, Ayrıntı 2019) 90-91. Aynı yönde bakınız Thomas Szasz, Yalanlar Bilimi Psikiyatri Çeviren Nur Küçük (Aylak Kitap 2013) 35, 39. Lemke, biyopolitika kavramını irdelediği eserinde bunun politikadan dışlanan “öteki” yi yeniden içerdiğini belirterek dolaylı olarak bu hususa değinmektedir. Thomas Lemke, Biyopolitika Çeviren Utku Özmakas (4. Bası, İletişim 2017) 153. 
olmamasıyla açıklanamayacak düzeydedir. ${ }^{20}$ Zira çok küçük yaştaki çocuklar veya zihinsel engelli bireyler de benzer bir durumdadır. ${ }^{21}$ İnsanın sırf insan olmasından ötürü araçsallaştırılamayacağı kabulünün temelinde irade sahibi bir varlık olması değil, araçsallaştıran öznenin bizzat insan olmasından ötürü kendi türünü araçsallaştırmasının mantıksal tutarsızlığının bulunduğu ileri sürülebilir. Dolayısıyla etiği ve buna bağlı olarak hukuku biçimlendiren, varlıkları disiplin altına sokan ve hegemonya kuran iktidarın biyopolitikasından başka bir şey değildir. ${ }^{22}$ Öyle ki neyin hastalık olup olmadığı dahi sosyokültürel ${ }^{23}$ ve politik bir meseledir. ${ }^{24}$ Sonuç itibariyle tıbbi müdahaleden anlaşılması gereken, psikososyal tabiatı olan canlı bir varlığa onu fizyolojik olarak veya psikolojik veya sosyal olarak etkileyebilen ve biyoloji ve tıbbın elde ettiği bilgiler kullanılarak tıbbi yöntemlerle gerçekleştirilen her tür girişimdir.

\section{B. Onam Hakkının Temelleri: Özerklik Hakkının ve Kişiliğin Korunması}

Bir kimseye yönelik müdahalelerin hukuka uygun olabilmesi için kendisinden önceden onam alınmış olması koşulunun ${ }^{25}$ temelinde bireyin kendi yaşamını, geleceğini kendisinin yönetme hakkına sahip olması bulunmaktadır. ${ }^{26}$ Bireyin özerk varlık sayılmasının sebebi insanların özgür olması, başka birinin egemenliğine tabi olmaması yönündeki kabuldür. Öyle ki bazı bireyler muhakeme ve irade oluşturma kabiliyetinden yoksun olsa dahi özgürdür ve her koşulda özne konumundadır. İnsanın birey olarak, özgür bir özne olarak kabulü liberalizme dayanmaktadır. Liberalizm öncesinde patriyarkal toplum düzeninde köleler, kadınlar ve çocukların özgür olmadığı, Roma hukukunda pater familias olarak adlandırılan aile babasının kendisine tabi olan insanların yaşamı, özgürlüğü ve bedenleri üzerinde dilediği gibi tasarrufta bulunabildiği bilinen bir gerçektir. ${ }^{27}$

İnsan Hakları Bildirileri ve Sözleşmeleri ile birlikte kendisine hukuksal zemin bulan tabii haklar doktrini giderek insan hakları hukukunun gelişimini sağlamıştır. ${ }^{28}$ Böylece

20 İnsan onuru kavramının türcülüğe varan bir boyutu olduğu ve hayvanların insan yararı için araçsallaştırılmasının olağan görülmesine yönelik eleştiriler için bakınız Metin (n 13) 473-474; Gürbüz (n 13) 41 vd

21 Türel tutarlılık ilkesi olarak belirtilen Gewirth tarafından savunulan görüş çerçevesinde çocuklar, zihinsel engelliler ve hayvanlar türel haklara sahip olmak için aranan en az müstakbel özne statüsünün dışında kalmaktadır. Bu görüş için bakınız Gürbüz (n 13) 51 .

22 Bakınız Utku Özmakas, Biyopolitika: İktidar ve Direniş Foucault, Agamben, Hardt-Negri (2. Bası, İletişim 2019) 59-60.

23 Foucault, hastalığın hastalık gerçekliğine ve değerine sahip olmasının bu şekilde tanımlandığı bir kültür içinde mümkün olduğuna vurgu yapmaktadır. Bakınız Foucault, Akıl Hastalığı ve Psikoloji (n 19) 78.

24 Foucault, zihinsel tıp ve organik tıp ayrımı yapmakta ve organik tıpta patolojik olanla normal olanın birbirinden ayrılmasında organizmanın fizyolojik belirtilerinin tutarlı olduğuna, buna karşılık zihinsel tıp yani psikiyatride kişilik olgusunun normal ile patolojik olanı birbirinden ayırmayı güçleştirdiğine işaret etmektedir. Bakınız Foucault, Akıl Hastalığı ve Psikoloji (n 19) 11, 20-21. Aynı yönde bakınız Szasz, Yalanlar Bilimi Psikiyatri (n 19) 34-35. Buradan yola çıkıldığında fizyolojik bir patolojiye müdahalede bulunulmadığında kişinin yaşamını veya yaşamsal organlarını kaybetme riskiyle karşı karşıya kalmasına rağmen zihinsel patolojide müdahale edilmediğinde genel olarak ve doğrudan doğruya böyle bir risk söz konusu olmamaktadır. Söz konusu risk zihinsel hastalıklarda daha dolaylı şekilde gerçekleşmektedir.

25 Mustafa Dural ve Tufan Öğüz, Türk Özel Hukuku Cilt II Kişiler Hukuku (20. Bası, Filiz 2019) 106; Ahmet Kılıçoğlu, Medeni Hukuk Temel Kavramlar Başlangıç Hükümleri Kişiler Hukuku (Turhan 2016) 353; Oğuzman, Seliçi ve Oktay Özdemir (n 5) 180

26 Zarife Şenocak, 'Küçüğün Tıbbi Müdahaleye Rızası' (2001) 50(4) AÜHFD 65.

27 Gökçe Serim, Roma İmparatorluk Döneminde Aile Hukukuna İlişkin Düzenlemeler (Lykeion 2018) 14-16, $20-21$.

28 Münci Kapani, Kamu Hürriyetleri (7. Bas1, Yetkin 1993) 30-33. 
ayırt etme gücüne sahip olsun olmasın her insanın doğuştan sahip olduğu haklar güvence altına alınmıştır. Söz konusu tabii hakların başında özgürlük ve dolayısıyla özel yaşama sayg1 hakk1 gelmektedir. Kendi bedeni, ilişkileri, yaşamı konusunda tek başına karar verebilmek, bu hususta kendisine yönelecek müdahalelerden korunmak ve seçimlerinin sonuçlarına katlanmak özerklik hakkının kapsamını oluşturmaktadır. ${ }^{29}$ Söz konusu kararları alabilme özgürlüğü ile müdahalelerden korunma hakkı özel hukukta düzenlenen kişilik hakkının da temelini oluşturur.

Her insanın özgür olması gereği insanlar kendi seçimlerini yapmaya yeterli bir varlık olarak tasavvur edilmekle birlikte bu tasavvur ve varsayım her durumda gerçeklerle örtüşmemektedir. Olan biteni idrak etme, meydana gelen olayların sebep ve sonuçları arasında muhakeme yapabilme, ortaya çıkan ihtimalleri ve seçenekleri değerlendirerek seçim yapma ve irade oluşturabilme yeterliğinin yani ayırt etme gücünün olmadığı hallerde kişilerin özerklik hakkını bizzat kendi eylemleriyle koruması güçleşmektedir. ${ }^{30}$ Ayırt etme gücünden yoksun kişilerin muhakeme yapabilme yeterliğinden yoksun olması sebebiyle iradeleri gerçek değil doğal niteliktedir, canlı bir varlık olmayla ilişkili nitelikte verilen tepkiler kişinin doğal iradesini oluşturur. Ancak söz konusu doğal iradeye gerçek irade ölçüsünde bağlayıcılık atfedilmemiş olması sebebiyle ayırt etme gücünden yoksun kişilerin özerklik hakkının korunabilmesi hukuksal güvenlik ve öngörülebilirlik ihtiyacının giderilmesiyle mümkün olur. ${ }^{31}$ Çocuklar veya ayırt etme gücünden yoksun diğer kişiler adına alınacak kararların her defasında farklı bir kişi tarafından veya rastlantısal biçimde farklı kişilerce alınması söz konusu kişilerin özel yaşamına müdahale anlamına gelir. Buna karşılık ilgili kişiler için tayin edilmiş sürekli yasal temsilciye yetki ve sorumluluk yüklenmesi ayırt etme gücünden yoksun kişilerin üçüncü kişilere karşı özgür ve müdahalelerden uzak şekilde yaşamını düzenleyebilmesine olanak sağlar. ${ }^{32}$

\section{Onamın Tıbbi Müdahaleye Özgü Geçerlilik Koşulları}

\section{1. İlgilinin veya Yasal Temsilcisinin Aydınlatılması}

Herhangi bir müdahaleye onam vermek için kişinin özel olarak aydınlatılmasına genellikle ihtiyaç olmaz, ilgili kişi ortalama zekaya sahip olduğu takdirde müdahalenin kendisine verebileceği zararları öngörebilecek, bilebilecek durumdadır. Ancak tıbbi müdahalelerde tıbbın ve biyoloji biliminin elde ettiği özel bilgiler kullanıldığı için

\footnotetext{
Biyoetik ve biyotıp hukukunda özerklikle ilgili yapılan değerlendirmeler genellikle Kant'ın görüşlerine dayandırılmaktadır. Kant, insanın doğal belirlenim alanında olmakla birlikte ahlaki eylemleri yönünden özerk olduğunu ileri sürmektedir. Bakınız Kalkan Oğuztürk (n 13) 25-26.

30 Ayrıca bakınız Kalkan Oğuztürk (n 13) 25-26.

31 Bakınız Ertem (n 12) 662.

32 Aynı yönde bakınız Arif Barış Özbilen, İnsan Kökenli Biyolojik Maddelere İlişkin Hukuki İşlemler (Vedat 2011) 285-286.
} 
söz konusu özel bilgiler kendisine müdahale yapılacak kişide eksiktir. ${ }^{33}$ Kendisine ne kadar bilgilendirme yapılırsa yapılsın müdahaleyi yapacak tabip kadar konuya vakıf olması ve müdahalenin olası etkilerini onun kadar kavraması da mümkün değildir. ${ }^{34}$ Bununla birlikte ilgilinin kendi bedeni, yaşamı hakkında karar verebilmesini sağlamak için asgari ölçüde aydınlatma bir zorunluluktur. ${ }^{35} \mathrm{Bu}$ noktada kişinin müdahalenin olası yararları ile olası zararları hakkında anlayabileceği şekilde bilgilendirilerek kendi doğrularına göre seçim yapmasına yardımcı olmak, yol göstermek, yolunu aydınlatmak hedeftir. ${ }^{36}$ Öyle ki aydınlatmadan alınmış onama dayanarak müdahalede bulunulduğunda görünüşte müdahalenin yapılıp yapılmayacağına karar veren ilgili kişi olmakla birlikte gerçekte buna karar veren ilgiliden bu bilgileri esirgeyerek müdahaleyi yapan kişidir. ${ }^{37} \mathrm{Bu}$ nedenle aydınlatmadan alınan onama dayanan müdahale özerklik hakkını açıkça ihlal eder ve hukuka aykırı düşer. Aydınlatmanın diğer amacı da hastanın güvenliğini sağlayabilmektir, hastanın bilmeden, sonuçlarını öngöremediği için kendisine zarar verecek davranışlardan kaçınması amacıyla da ilgilinin durumu ve önerilen tıbbi müdahalenin kapsamı, niteliği ve sonuçları hakkında ilgilinin aydınlatılması gereklidir. ${ }^{38}$ Aydınlatmanın diğer bir işlevi de meydana gelebilecek risklerin gerçekleşmesi halinde müdahalede bulunanın sorumluluktan kurtulmasıdır. Aydınlatmanın tüm amaçları ve işlevleri yönünden ortak olan husus sürecin hastanın/danışanın kendi kontrolünde, hâkimiyetinde ilerlemesini temin etmektir.

Özerklik hakkı gereği aydınlatılması gereken kişi, müdahaleye onam verme hakkı olan kişidir. ${ }^{39}$ Zira aydınlatmanın amacı bireyin özerklik hakkına saygı göstermek, kişinin kendi yaşamını, bedenini, ilişkilerini kendi iradesi doğrultusunda düzenleyebilmesini temin etmektir. ${ }^{40} \mathrm{Bu}$ bakımdan kişi küçük veya kısıtlı olsa dahi kendi iradesi belirleyicidir, kişinin kişilik değerlerine yönelen müdahalelere ilişkin vereceği onam hakkı kişiye sıkı sıkıya bağlı niteliktedir. ${ }^{41}$ Dolayısıyla hastanın/ danışanın üzülmemesi için veya başka bir sebeple hasta/danışan yerine herhangi bir yakınının bilgilendirilmesihastanın özerklik hakkının açık bir ihlalidir. Bununla birlikte hasta kendisi yanında başkasının da bilgilendirilmesini isterse bu onam çerçevesinde ve sınırları içinde olmak üzere söz konusu kişi de bilgilendirilebilecektir. Hastanın

\footnotetext{
Zihinsel patolojilerde fizyolojik olanlardan farklı olarak hastanın hastalığa ilişkin özgün bir bilince sahip olduğu, hastanın kendisiyle ilgili hiçbir şey bilmeyen konumda olmadığı, hekimin de tüm bilgileri elinde tutan konumda olmadığ ileri sürülmektedir. Bakınız Foucault, Akıl Hastalığı ve Psikoloji (n 19) 61.

34 Bakınız Özbilen (n 32) 288.

35 Ertem (n 12) 389-390. Aynı yönde bakınız Özbilen (n 32) 293-294; Kirkit (n 1 ) 69.

36 Şenocak (n 26) 68; Kirkit (n 1) 76 vd

37 Bakınız Gürkan Sert, Uluslararası Bildirgeler ve Tıp Etiği Açısından Hasta Haklarl (2. Bası, Seçkin 2019) 138-139.

38 Kirkit (n 1) $71 \mathrm{vd}$

39 Şenocak (n 26) 80.

40 Özge Yücel, Ayırt Etme Gücünden Yoksun Kişiler Adına Alınan Tıbbi Kararlarda Özerklik Hakkının Korunması ve Hasta Talimatları (Seçkin 2018) 120; Şenocak (n 26) 68; Serdar Nart, 'Endikasyon Dışı İlaç Tedavisinde Hekimin ve İlaç Üreticisinin Hukuki Sorumluluğu'. (2017) 19 (Özel Sayı) DEÜHFD (Prof. Dr. Şeref Ertaş’a Armağan) 729, 747-748.

41 Dural ve Öğ̈̈z (n 25) 106; Şenocak (n 26) 73.
} 
onam verme yeterliği yani ayırt etme gücü bulunduğu halde aydınlatılmaktan vazgeçip vazgeçemeyeceği tartışma konusu olmuştur. ${ }^{42}$ Öğretide bunu mümkün gören yazarlar bulunmakla birlikte kanaatimizce aydınlatılmaktan tümüyle vazgeçmek ve mutlak bilgisizliği seçmek müdahalenin reddedildiği anlamına gelir. ${ }^{43}$ Mutlak bilgisizlik içinde tıbbi müdahaleye verilen onam geçerli olamaz, buna karşılık müdahalenin anlamı, amacı ve riskleri hakkında genel olarak asgari ölçüde bilgilendirme onam vermek için yeterli sayılabilir. ${ }^{44}$ Öte yandan Türk Medeni Kanunu'nun 16. maddesi ile 1219 sayılı Tababet ve Şuabatı Sanatlarının Tarzı İcrasına Dair Kanun'un 70. maddesi gereğince hasta/danışanın ehliyetli olmaması yani ayırt etme gücünden yoksun olması ya da küçük veya kısıtlı olması halinde -tek başına veya ilgilinin onamıyla birlikte- yasal temsilcinin onamı gerekli olduğu için Hasta Hakları Yönetmeliği'nin 31. maddesinin ilk fikrasina göre yasal temsilcinin de bizzat müdahalede bulunacak kişi tarafından aydınlatılması gerekir. ${ }^{45}$

\section{Yetkili Kişiye Onam Verilmesi}

Tıbbi müdahalenin biyoloji, psikoloji ve tıp biliminin ulaştığı bilimsel bilgiler doğrultusunda niteliği, kapsamı ve sonuçları yalnızca uzman olan kişilerce bilinen bir müdahale olması gereği diğer müdahalelerden farklı olarak herhangi bir kişiye verilecek onam geçerli olamaz. ${ }^{46}$ Bu bağlamda bilimsel bilginin kötüye kullanılmasını önleme amacının söz konusu olduğu açıktır. Zira bilgi tehlikeli bir araçtır, iyi ve meşru amaçlar için kullanılabileceği gibi kötü amaçlar için de kullanılabilir. Bilginin kötüye kullanılmamasının yolu tıbbı uygulamaya yetkili olan kişilerin doğru belirlenmesi ve mesleki özerklik korunarak bağımsız kurullar tarafından denetlenmesidir. Bunun yanında bilimsel bilgi veya teknoloji yanlış şekilde kullanıldığında hem birey hem halk sağlığı için zararlı sonuçlar doğması kuvvetle muhtemel olduğu için kişinin kendisinden, yaşamından, sağlığından vazgeçmesi anlamına gelebilecek bir onam kişilik hakkıyla bağdaşmaz ve hukuka uygun sayılamaz, bu nedenle müdahaleyi meşru kılamaz.

Dolayısıyla yalnızca diploması onaylanmış olan, kanunla yetki sınırları çizilmiş sağlık meslek mensuplarının tıbbi müdahaleler uygulamasına izin vermek hukuka

\footnotetext{
42 Aydınlatma yükümlülüğünün daraldığı veya ortadan kalktığı durumlara ilişkin olarak Bakınız Nart (n 40) 755-756; Sert (n 37) $161 \mathrm{vd}$

43 Bu konudaki tartışma için bakınız Nart (n 40) 755-756; Nart (n 1) 279, 292-293; Yücel (n 40) 120-121.

44 Aynı yönde bakınız Özbilen (n 32) 294-295; Kirkit (n 1) 94; Nart (n 40) 755. Nart, aydınlatmanın temel hatlarıyla mı kapsamlı, ayrıntılı şekilde mi yapılması gerektiği şeklinde iki seçenek üzerinde durarak amacın hastanın kendi geleceği hakkında karar verme olanağını sağlamak olduğuna işaret etmektedir.

451219 sayılı yasanın 70. maddesinde tamamlayıcı olarak onam arayan hükme karşın öğretide bazı yazarlara göre her tıbbi müdahale için değil TMK madde 16 gereği ciddi ve önemli tıbbi müdahaleler için yasal temsilcinin onamı aranır. Bakınız Rona Serozan, Medeni Hukuk Genel Bölüm Kişiler Hukuku (7. Bası, Vedat 2017) 469-470; Şenocak (n 26) 73-79. Buna karşılık 1219 sayılı yasayı TMK hükümlerinden bağımsız șekilde yorumlayarak hastanın ayırt etme gücüne bakılmaksızın salt yasal temsilcinin onamının aranacağını belirten görüş için bakınız Dural ve Öğüz (n 25) 107. Buna karşılık her durumda salt sınırlı ehliyetsizin onamının yeterli olduğunu belirten görüş için bakınız Nart (n 1) 39.

46 Tıbbi müdahalede bulunmaya yetkili olma koşulu için bakınız Kirkit (n 1) 18 vd
} 
uygun olacaktır. ${ }^{47} \mathrm{~T} 1 \mathrm{bb}$ uygulamaya yetkili olan kişilerin yalnız tıp fakültesi mezunları olmayıp Hemşirelik Kanunu'na göre hemşirelerin, Eczacilar ve Eczaneler Hakkında Kanun'a göre eczacıların, 1219 sayılı Tababet ve Şuabatı Sanatlarının Tarzı İcrasına Dair Kanun'un 29. maddesine göre diş hekimlerinin, Ek 13. maddesine göre klinik psikologlar, fizyoterapistler gibi sağlık meslek mensuplarının da yetkili olduklarına dikkat çekmek gerekir. Elbette bir kimse kendi bedenine tıbbi müdahalede bulunurken yetkili olup olmadığı sorgulanmayacaktır. Burada önemli olan bir başkasının bedenine dolayısıyla kişiliğine yönelen müdahalenin hangi koşullarda meşru sayılabileceğidir.

\section{Meşru Amaç İçin Onam Verilmesi}

Tıbbi müdahalelerin hukuka uygun olabilmesinin koşulu olarak sıklıkla tıbbi gerekliliğin varlığı ileri sürülse ${ }^{48}$ de bu kavram onam hakkının sınırlarını yeterli ölçüde açılamaya elverişli olmaktan uzaktır. Öğretide bu kavrama dayanılmasının bir nedeni Anayasa madde 17'de tıbbi zorunluluklar ve kanunda yazılı haller dışında beden bütünlüğüne dokunulamayacağının öngörülmesidir. Fakat esasında burada öngörülen anayasal hüküm kişinin iradesine aykırı olarak hangi durumlarda tıbbi müdahalede bulunulacağını açıklamaya yöneliktir.

Onam hakkının sınırları yönünden tıbbi gereklilik iddiasının temelinde tıp etiğinin en temel ilkelerinden yararlılık ilkesi olduğunu ileri sürmek daha gerçekçi olacaktır. Bir başka ifadeyle kişilere yarar sağlamayacak bir tıbbi müdahalenin yapılması ahlaki ve dolayısıyla meşru karşılanmamaktadır. Çünkü tıbbi gereklilik kriterine dayanıldığında, tıbbi gereklilik hastalığı önleme, teşhis, tedavi ve rehabilitasyonla sınırlı olarak değerlendirildiği için, herhangi bir hastalıkla ilgisi bulunmayan kürtaj, sünnet, üremeye yardımcı tıbbi müdahaleler gibi müdahalelerin meşruluğunu tıbbi gereklilik kavramı açıklayamamaktadır. Neyin hastalık olup olmadığ 1 konusunda yapılan tıbbi değerlendirmeler nasıl ki salt bilimsel olmayıp psikososyal görüş ve yaklaşımlardan bağımsız değilse tıbbi müdahalenin hangi durumda gerekli olup olmadığına ilişkin verilecek kararlar da farklı değildir. Bu bağlamda insan onuru kavramına sığınarak paternalist bir yaklaşımla herhangi bir tıbbi müdahalenin gerekli olmadığı, dolayısıyla hukuka uygun olmadığı ileri sürülebilecektir. ${ }^{49}$

İlgilinin özerklik hakkına saygı duyulabilmesi bakımından tıbbi müdahalenin hukuka uygunluğu için onamın meşru bir amaca, en geniş anlamıyla "yarar sağlamaya"50 yönelik olması koşulu aranmalıdır. Böyle bir yaklaşım Türk Medeni

\footnotetext{
47 Serap Helvacı, Gerçek Kişiler (2. Bası, Arıkan 2007) 77.

48 Bakınız Dural ve Öğüz (n 25) 106. Badur, "sağlık refahının sağlanması, korunması veya artırılması" amacına yönelik olmasını aramaktadır. Bakınız Badur (n 1) 39. Kirkit ise "hukuken öngörülmüş amaçlara yönelme" ifadesini kullanmış ve tıbbi gereklilik yanında nüfus planlamasını da bu amaçlara dahil etmiştir. Bakınız Kirkit (n 1) 35 vd

49 Bakınız Gürbüz (n 13) 23-26.

50 Yarar sağlama ilkesinin onam alınamadığı hallerde kişinin muhtemel iradesiyle çatışabileceği açıktır. Bakınız Hilal Yüksel, Kişilik Hakkı İhlali Kapsamında İnsan Üzerinde Yapılan Deneyler ve Hukuki Sonuçları (On İki Levha 2017) 37.
} 
Kanunu'nun 23. maddesine de uygun düşecektir. ${ }^{51}$ Dolayısıyla tıbbi müdahaleler açısından zarar vermeme ilkesi üstün tutularak kişinin biyoloji ve tıbbın bilgi ve yöntemlerinden yararlanma hakkı olduğu kabul edilmelidir. ${ }^{52}$ Böylece tıbbi gereklilik olduğu kabul edilen haller dışındaki tıbbi müdahaleler için psikolojik, sosyal endikasyon gibi zorlama gerekçeler bulmaktan vazgeçilebilir. ${ }^{53} \mathrm{Bu}$ doğrultuda teşhis, tedavi, rehabilitasyon, önleme veya hastalığın etkilerinin hafifletilmesi amaciyla tıbbi müdahaleler kadar kişinin istediği zaman ve istediği çoklukta üreme hakkını kullanabilmek için gebeliğin sonlandırılması, sterilizasyon, üremeye yardımcı tekniklere başvurulması veya bedenini cinsiyet kimliğine uyumlu hale getirmek amacıyla cinsiyet değişikliği operasyonu geçirmek istemesi de meşru bir amaca yöneliktir. Bu kapsamda bireyin hiçbir üreme organına sahip olmak istememesi, feminen veya maskülen gösterecek fiziksel özelliklerinden kurtulmak istemesi de mümkündür. Ancak kişilerin her isteğinin meşru olmayabileceği açıktır. Dural ve Öğüz’ün belirttiği gibi yapılacak müdahale kişiliğin tahribine değil, idamesine yönelmiş olmalıdır. ${ }^{54}$ Örnek vermek gerekirse gözlerinden birinin görme yetisine son verilmesini istemesi ya da sebep olmadığ 1 halde bacağının kesilmesini istemesi durumunda kişinin hayatta kalabilmek için temel becerilerden kendisini yoksun bırakacak müdahalelerin meşru olduğu ileri sürülemez. Böyle bir müdahalenin yapılması halinde kişinin onamına dayansa dahi tıp etiği ve tıp hukuku için geçerli olan "zarar vermeme" ilkesinin ${ }^{55}$ ihlal edileceğinde kuşku yoktur. Aktif ötanaziye izin verilen ülkelerde aktif ötanaziye onamın hukuka uygun olması için de aynı şekilde meşru amaç koşulu aranmaktadır, iyileşmesi mümkün olmayan bir hastalığa yakalanmış olma ve çekilen acılardan kurtulma amacının varlı̆̆ı tespit edildiğinde bir kimsenin yaşamına son verecek bir müdahaleye onam geçerli sayılabilmektedir. ${ }^{56}$ Böylece müdahaleden beklenen sakıncaların beklenen yarardan ağır basmaması beklenmektedir. ${ }^{57}$ Benzer şekilde salt bilimsel amaçlı deneylere veya organ transplantasyonuna verilecek onamın geçerliliği de meşru amacın yani üstün kamu yararının veya başkasının üstün yararının beklenen risklere göre baskın gelmesine bağlıdır. ${ }^{58}$

51 TMK madde 23’te öngörülen koruyucu hükmün özgün yorumu için bakınız Serozan, Medeni Hukuk (n 45) 458-459. Serozan tıpkı temel hak ve özgürlüklere doğrudan doğruya getirilen kısıtlamalarda olduğu gibi birbiriyle çatışan menfaatler arasında denge ve ölçülülük kriterinden yola çıkarak TMK madde 23 hükmünü somutlaştırmaktadır. Yazara göre ahlaka aykırılık belirlenirken kavramcı ayrımcılıktan kaçınılmalı, özveri ve ödünün kiş̧i için ağırlığı, sağlayabileceği yararlar, başkalarının sağlayabileceği menfaatin ağırlığı ve ödün verenin ekonomik, sosyal, zihinsel güçsüzlügünün birlikte değerlendirilmesi gerekmektedir. Bakınız Serozan, Medeni Hukuk (n 45) 458, 463.

52 Verilen örnekler dikkate alındığında aynı yönde bakınız Serozan, Medeni Hukuk (n 45) 461.

53 Aynı yönde bakınız Ertem (n 12) 54.

54 Dural ve Öğüz (n 25) 108.

55 Zarar vermeme ilkesi ve diğer ilkeler için bakınız Kalkan Oğuztürk (n 13) 119 vd; Yüksel (n 50) 34 vd; Dumancı (n 18) 57-63.

56 Bakınız Gürbüz (n 13) 100-101, 107.

57 Oğuzman, Seliçi ve Oktay-Özdemir (n 5) 180.

58 Öğretide "daha üstün yarar" hukuka uygunluk sebebinin onama dayalı deneylerde bir gerekçe olarak kullanılması fikrine katılmak mümkün değildir. Bu görüş için bakınız Kirkit (n 1) 152. Kanaatimizce "daha üstün yarar" kavramı onam dışı saldırıları meşru kılabilir, onama dayalı müdahalelerde ise toplumun yararının aranması onamın geçerliliği için aranan meşru amaç ölçütüyle açılanabilir. 


\section{Onam Hakkının Kategorik Sınırlandırılma Sebepleri ve Usulü}

\section{Anayasal ve Yasal Sinırlandırma Sebepleri}

Kişinin bedenine dışarıdan ve onun iradesi dışında olmak üzere yönelecek her tür müdahale yönünden, bir başka ifadeyle kişinin geçerli bir onamı olmadığı halde müdahalede bulunulabilmesi için müdahalede bulunanın yasanın verdiği bir yetkiye dayanması gerekmektedir. Bedenin müdahalelere karşı korunması en temel hak ve özgürlükler arasında olduğu içindir ki insan haklarına ilişkin uluslararası sözleşmeler ve Anayasa hükümleri doğrultusunda öngörülen yasal düzenlemelere dayanarak böyle bir müdahalede bulunulması meşru sayılabilir. ${ }^{59} \mathrm{Bu}$ noktada kişinin iradesi dışında ifadesiyle kast edilen, yalnızca onun açık reddine rağmen müdahale bulunulması değil, aynı zamanda onun bilgisi olmaksızın, ona sorulmaksızın, yani açıkça onamı alınmaksızın müdahalede bulunulmasıdır. Anayasanın ve uluslararası sözleşme hükümlerinin özel hukuk ilişkilerinde doğrudan uygulanmasını gerektiren durumların başında kişilik hakkına yönelik müdahaleler gelmektedir. ${ }^{60}$

Anayasanın 13. maddesine göre temel hak ve özgürlükler yalnızca Anayasanın ilgili maddelerinde belirtilen sebeplere yani özel sınırlandırma sebeplerine bağlı olarak sınırlandırılabilir. ${ }^{61}$ Beden bütünlüğünün dokunulmazlığına ilişkin olarak Anayasa madde 17 'de öngörülen sınırlandırma sebebi “tıbbi zorunluluklar ve kanunda yazılı haller" olarak belirtilmiştir. Tibbi zorunlulukların ne anlama geldiği anlaşılabilirse de bunun dışındaki sebeplerin açıkça belirtilmeyip kanunda yazılı haller şeklinde açıklanması Anayasanın 13. maddesiyle tutarlı görünmemektedir. Bu noktada her hak gibi temel hak ve özgürlüklerin de kötüye kullanılamayacağ 1 , her hakkın bünyesindeki koruma menfaatinin sınırlarına uyulması gerektiği kabul edilmektedir. ${ }^{62} \mathrm{Bu}$ noktada üstün yarar kavramı kanaatimizce hakkın kötüye kullanılmasının önüne geçilmesi için başvurulan bir sınırlandırma gerekçesi olarak kullanılmaktadır. Ancak üstün yarar kavramına Anayasada değil Türk Medeni Kanunu'nda yer verilmektedir. Türk Medeni Kanunu'nun özel hukuk açısından genel hüküm niteliği taşıyan ve ilkesel bir düzenleme olan 24. maddesinin ikinci fikrasına göre "Kişilik hakkı zedelenen kimsenin rızasl, daha üstün nitelikte özel veya kamusal yarar ya da kanunun verdiği yetkinin kullanılması sebeplerinden biriyle haklı kılınmadıkça, kişilik haklarına yapılan her saldırı hukuka aykırıdır". Söz konusu düzenlemenin Anayasa madde 17'de öngörülen hükmün tamamlayıcısı niteliğinde olduğunu ileri sürmek yanlış olmayacaktır. TMK madde 24 'te açıklanan üstün nitelikte özel yarar veya kamusal

\footnotetext{
Bülent Tanör ve Necmi Yüzbaşığlu, 1982 Anayasasına Göre Türk Anayasa Hukuku (19. Bası, Beta 2019) 147.

60 Aynı yönde bakınız Metin (n 13) 377.

61 Bu konuda ayrıntılı bilgi için bakınız Ergun Özbudun, Türk Anayasa Hukuku (7. Bası, Yetkin 2002) 99 vd; Tanör ve Yüzbaşığlu (n 59) 150-151. COVID-19 salgınıyla mücadele kapsamında getirilen yasak ve kısıtlamaların Anayasaya aykırılığı hakkında değerlendirme için bakınız Kemal Gözler, Türk Anayasa Hukuku Dersleri (25. Bası, Ekin 2020) 400.

62 Tanör ve Yüzbaşığlu (n 59) 146-147; Özbudun (n 61) 103, 109; Mehmet Sağlam, 'Ekim 2001 Tarihinde Yapılan Anayasa Değişiklikleri Sonrasında, Düzenlendikleri Maddede Hiçbir Sınırlama Nedenine Yer Verilmemiş Olan Temel Hak ve Özgürlüklerin Sınırı Sorunu' (2002) 18(1) Anayasa Yargısı Dergisi 233, 254-255.
} 
yarar kriteri soyut ve genel bir sınırlandırma sebebi oluşturmaktadır, hangi hallerde daha üstün nitelikte özel veya kamusal yarar olduğu yine yasalarda öngörülen sınırlandırmalar ile tespit edilebilecektir. ${ }^{63}$ Zira daha üstün nitelikte özel yararın hangi durumda var olduğunu tespit etmek salt idari ve yargısal otoritelere bırakılmış olsaydı temel hak ve özgürlüklerin objektif olarak değil sübjektif ve dolayısıyla keyfi olarak sınırlandırılması sonucu ile karşılaşılırdı ve böyle bir sonuç Anayasaya aykırı düşeceği için kabul edilemez. ${ }^{64}$

Türkiye'nin tarafı olduğu ve Anayasa madde 90 gereğince kanun hükmünde sayılan Biyolojinin ve Tibbın Uygulanması Bakımından İnsan Hakları ve İnsan Haysiyetinin Korunması Sözleşmesi: İnsan Hakları ve Biyotıp Sözleşmesi’nin 26. maddesinde bedene yönelik müdahalelere ilişkin olarak insan haklarının hangi gerekçelerle kısıtlanabileceği Anayasadan farklı olarak daha açık şekilde düzenlenmiş bulunmaktadır. "Hakların Kullanılmasının Kısıtlanması" başlığını taşıyan söz konusu maddeye göre "1. Bu Sözleşmede yer alan haklar ve koruyucu hükümlerin kullanılmasında, kamu güvenliği, suçun önlenmesi, kamu sağllğının korunması veya başkalarının hak ve özgürlüklerinin korunması için kanun tarafindan öngörülen ve demokratik bir toplumda gerekli olanlardan başka klsitlama konulmayacaktır. 2. Yukarıdaki paragrafta sözü edilen kisitlamalar, Madde 11, 13, 14, 16, 17, 19, 20 ve 21 'e uygulanmayacaktır." Esasen belirtilen sinırlandırma sebeplerinin nitelikleri göz önünde bulundurulduğunda ya başkalarının hak ve özgürlüklerinin korunması ifadesiyle kast edildiği gibi daha üstün nitelikte özel yararın korunması ya da kamu güvenliği, suçun önlenmesi, kamu sağlığının korunması ifadeleriyle kast edildiği gibi daha üstün nitelikte kamu yararının korunması amaçlanmaktadır. ${ }^{65}$ Bir başka ifadeyle kişinin gerçek iradesine rağmen temel hak ve özgürlüklerde yapılacak sınırlandırmalar başkalarının menfaatlerini koruma düşüncesine dayanır. ${ }^{66}$ İnsan genomu üzerindeki müdahaleler, insan üzerinde deneyler, canlı vericiden nakil amaciyla organ ve doku alınması konularında yukarıda belirtilen gerekçelerin yani kısaca üstün yararın insan haklarının sınırlandırılmasında gerekçe olarak gösterilemeyeceği açıkça belirtilmektedir. Böylelikle insanların metalaştırılmasında ve araçsallaştırılmasında tıbbın kullanılmasının önüne geçilmesi hedeflenmektedir.

Türkiye'nin tarafı olduğu ve dolayısıyla Anayasa gereği kanun hükmünde sayılan Avrupaİnsan HaklarıSözleşmesi’ndebedeneyönelikmüdahalelerözgürlükvegüvenlik hakkı ile özel hayata ve aile hayatına saygı hakkı olmak üzere iki ayrı bağlamda ele alınarak düzenlenmektedir. Bir kimsenin iradesine aykırı olarak bir yerde tutulması,

\footnotetext{
3 Soyut ve somut yasaklar ve sınırlandırmalar ayrımı için bakınız Tanör ve Yüzbaşıoğlu (n 59) 147-148.

64 Bakınız Tanör ve Yüzbaşığlu (n 59) 147.

${ }^{65}$ Sözleşmede söz konusu olan sınırlama ölçütlerinin Sözleşmenin konusu kapsamında ve amacıyla bağdaştı̆̆ ileri sürülmektedir. Bakınız Metin (n 13) 376-377.

${ }_{66}$ Tanör ve Yüzbaşığlu, temel hak ve özgürlük sınırlamalarının devlet ya da kamu kökenli gerekçeler yanında başkalarının hak ve özgürlüklerini korumak için de yapılabileceğini belirtmektedir. Bakınız Tanör ve Yüzbaşığlu (n 59) 147.
} 
alıkonulması, Sözleşmenin özgürlük ve güvenlik hakkına ilişkin 5. maddesinde, bedene ve psikososyal varlığa yönelik her tür tıbbi müdahale ise Sözleşmenin özel hayat ve aile hayatına saygı hakkına ilişkin 8. Maddesinde düzenlenmektedir. Özel hayat kavramı Sözleşme metninde somutlaştırılmış olmasa da Avrupa İnsan Hakları Mahkemesi'nin yerleşik içtihadına dayanan yorumlarında bu kavramın mahremiyeti aşan şekilde, özerkliği, kişinin bedeniyle ilgili kararların kendisine ait olması anlamlarını kapsayacak şekilde değerlendirildiği görülmektedir. ${ }^{67}$ Sözleşmenin 8 . maddesinin ikinci fikrasında sınırlandırma gerekçeleri şöyle açıklanmaktadır: " $B u$ hakkın kullanılmasına bir kamu makamının müdahalesi, ancak müdahalenin yasayla öngörülmüş ve demokratik bir toplumda ulusal güvenlik, kamu güvenliği, ülkenin ekonomik refahl, düzenin korunması, suç işlenmesinin önlenmesi, sağlığın veya ahlakın veya başkalarının hak ve özgürlüklerinin korunması için gerekli bir tedbir olması durumunda söz konusu olabilir’. Bu maddede sayılan gerekçelerin yalnızca tıbbi müdahaleler değil özel yaşama yönelik tüm müdahaleler için sinırlandırma gerekçeleri olduğu dikkate alındığında bu maddede sayılan tüm sebepler tıbbi müdahalelerle ilgili özerklik hakkının sınırlandırılması açısından meşru sayılamaz. İnsan Hakları ve Biyotıp Sözleşmesinin salt tıbbi müdahaleler yönünden temel hak ve özgürlükler için sınırlandırma sebepleri öngörüldüğü düşünülürse Avrupa İnsan Hakları Sözleşmesi’nde belirtilen diğer gerekçelerin (ülkenin ekonomik refahı, ahlak gibi) tıbbi müdahaleler için esas alınmaması gerekir. ${ }^{68}$

\section{Temel Hak ve Özgürlüklerin Sınırlandırılmasında Gözetilecek İlkeler}

Türk Medeni Kanunu madde 24'te kişilik hakkına müdahaleleri meşru kılacak sebepler belirtilmiş olmakla birlikte söz konusu meşru sebepler soyut biçimde ifade edilmiş, somutlaştırılmamıştır. Kişilik hakkının temel hak ve özgürlüklerin özel hukuktaki yansıması olduğu düşünüldüğünde Avrupa İnsan Hakları Sözleşmesinde, İnsan Hakları ve Biyotıp Sözleşmesinde ve Anayasada temel hak ve özgürlüklerin sınırlandırılmasının usulüne ilişkin öngörülen ilkelerin gözetilmesi gerekmektedir. ${ }^{69}$ Belirtmek gerekir ki TMK madde 23 hükmü de TMK madde 24 gibi bireyin özerkliğine sınırlandırma getirmektedir. ${ }^{70}$ Ancak TMK madde 23 olumsuz şekilde sınırlandırma getirerek kişinin onamının hangi durumlarda geçerli olmayacağını açıklar ve kişinin onamına rağmen herhangi bir müdahaleyi meşru kılmaz iken TMK madde 24 hükmü olumlu surette sınırlandırmada bulunarak kişinin onamı dışında

\footnotetext{
${ }_{67}$ Ursula Kilkelly, The right to respect for private and family life, A guide to the implementation of Article 8 of the European Convention on Human Rights (Directorate General of Human Rights, Council of Europe 2003) 11, 14-15.

68 TBK madde 27' de belirtilen ahlak sınırlandırmasının Anayasa madde 13 karşısındaki meşruluğu biyoetik sorunlarla ilgili olarak öğretide tartışılsa da kanaatimizce ahlak kuralları, belirttiğimiz gerekçelerle kişinin onamı dışındaki müdahaleleri meşrulaştırmak açısından değil sözleşme özgürlüğunün sınırlandırılması bağlamında tartışılabilir. Bakınız ve karşılaştırınız Kalkan Oğuztürk (n 13) 72-75.

69 Serozan, Medeni Hukuk (n 45) 456.

70 Dural ve Öğüz (n 25) 151, 153-155; Oğuzman, Seliçi ve Oktay-Özdemir (n 5) 209-211.
} 
hangi hallerde müdahalenin hukuka uygun olduğunu açıklamaktadır. ${ }^{71}$ Dolayısıyla bu başlık altında olumlu tarzda özerkliğe ve kişilik hakkına yönelik sınırlandırmaların tabi olduğu kurallar açıklanmaktadır.

Anayasanın 13. maddesinegöre temelhakveözgürlükler,özlerine dokunulmaksızın, özel sınırlandırma sebeplerine bağlı olarak ve ancak kanunla sınırlanabilir. Maddenin ikinci cümlesinde bu sınırlamaların Anayasanın sözüne ve ruhuna, demokratik toplum düzeninin ve laik Cumhuriyetin gereklerine ve en önemlisi de ölçülülük ilkesine aykırı olamayacağı belirtilmektedir. İnsan Hakları ve Biyotıp Sözleşmesinin 26. maddesinde de "kanun tarafindan öngörülen ve demokratik bir toplumda gerekli olanlardan başka kısıtlama konulmayacaktır" hükmüyle sınırlandırmaların sınırı çizilmiş, sınırlandırmalar için gözetilecek ilkeler Anayasa madde 13 ile benzer şekilde öngörülmüştür.

Söz konusu düzenlemelerden hareketle temel hak ve özgürlüklerin sınırlandırılmasında gözetilecek ilkeler yasallık, öngörülebilirlik ve hukuksal güvenlik, amaç ve araç arasında orantının varlığı, bir başka ifadeyle ölçülülük olarak açıklanabilir. ${ }^{72}$ Somut sınırlandırma sebeplerinin tek tek yasayla düzenlenmesi gerekmektedir. Böylece bireyler hangi durumlarda nasıl bir sınırlandırma rejimiyle karşı karşıya kalacaklarını öngörebilecektir. Yasallık kriteri aynı zamanda sınırlandırmaların somut ve açık olmasını temin etmeye yöneliktir. Yasallık kriterinden hem maddi anlamda yasallık yani düzenlemenin genel ve objektifliği hem de şekli anlamda yasallık yani kararname, yönetmelik veya genelge değil adı kanun olan bir yasama faaliyeti ürünüyle sınırlandırma getirilmesi anlaşılmaktadır. ${ }^{73}$ Yasallık ölçütü sınırlandırma sebebinin her zaman kendiliğinden hakkın sınırlanması anlamına gelmez, yasal düzenleme hakkın sınırlandırılmasında hâkime veya başka bir kamusal otoriteye yetki tanımış olabilir. ${ }^{74}$ Böyle bir durumda kamusal otoritenin sınırlandırma ve böylece kişiliğe müdahale etme yetkisini kullanırken Anayasal ilkelere riayet etmesi gerekir. Öte yandan sınırlandırmaların ölçülü olması gereklidir. $\mathrm{Bu}$ bağlamda sınılandırmaların demokratik toplum düzeninin gereklerine aykırı olmamas1 gereği de hakkın özüne dokunmaması gereği de ölçülülük kriterinin bir başka ifadesi niteliğindedir. ${ }^{75}$

\footnotetext{
Serozan, Medeni Hukuk (n 45) 463, 471. TMK madde 23 ve 24'te öngörülen hükümlerin anlamı hakkında bakınız Helvacı (n 47) 104-109; Dural ve Öğüz (n 25) 151-155. Serozan, Medeni Hukuk (n 45) 457-473. Helvacı, haklı olarak TMK madde 23 ile kişinin kendisine karşı değil belirli durumlarda başka kişilerce zorlanarak karar verme özgürlügünün hukuksal işlem ile önceden sınırlandırılmasına karşı koruma sağlandığını belirtmektedir. Helvacı (n 47) 104-105.

72 Tanör ve Yüzbaşığlu (n 59) 157-167.

73 Tanör ve Yüzbaşığlu (n 59) 158.

74 Bakınız Tanör ve Yüzbaşığlu (n 59) 152-154.

75 Aynı yönde bakınız Tanör ve Yüzbaşığlu (n 59) 163-165; Özbudun (n 61) 104-107.
} 


\section{Onam Hakkının Sınırı Olarak Üstün Özel Yarar}

Kişiliğe müdahalenin haklı sebeplerinden biri olan daha üstün nitelikte özel yarar, kendisine müdahalede bulunulacak kişinin yararı olabileceği gibi başka bir kişinin yararı da olabilir. ${ }^{76}$ Belirtmek gerekir ki kişiye kendi menfaatinin korunması için iradesi dışında müdahalede bulunulabilmesi için kişinin geçici veya sürekli olarak ayırt etme gücüne sahip olmaması gerekir. Zira ayırt etme gücüne sahip bir kimseyi kendisine rağmen kendisinden korumak iddiasıyla müdahalede bulunmak kişilik hakkına yönelik ölçüsüz bir sınırlandırma oluşturur.

\section{A. Kişinin Kendi Yararına Tıbbi Müdahalelerde}

\section{Yasal Temsilciye Rağmen Aşılama, Muayene ve Tedavi}

Veli veya vasinin bakım ve gözetim ile yükümlü olduğu çocuklar ve ayırt etme gücünden yoksun erginler, özerklik hakk1 ayırt etme gücünün eksikliği halinde yasal temsilcileri aracılığıyla korunabilecektir. ${ }^{77}$ Hukuksal güvenlik ihtiyacının karşılanması ayırt etme gücü bulunmayan kişiler adına alınacak kararların sürekli olarak öngörülebilir bir kişi tarafından alınması ile mümkün olabilir. Zira kayyımın aksine sürekli olarak görev yapmak üzere belirlenen yasal temsilci yani veli veya vasi ilgilinin ihtiyaçlarını, kişiliğini, duygu ve düşüncelerini, isteklerini genellikle en iyi anlayabilecek kişidir. İlgilinin görüşlerinin ayırt etme gücü olsun olmasın mümkün olduğu ölçüde öğrenilmesi hususunda yasal temsilciye yüklenen yükümlülük kişilerin özerklik hakkına saygı duyulmasını mümkün kılmakta ve bunu güvence altına almaktadır.

Ayırt etme gücü bulunmayan kişilere yönelik tıbbi müdahaleler için 1219 sayılı yasaya göre onam verme yetkisi veliye veya vasiye aittir. Ancak veli veya vasi onam vermekten kaçındığı takdirde onaylamadıkları müdahale kendi bedenlerine ilişkin değil başka bir kişinin bedenine ilişkin olduğundan velinin veya vasinin tartışmasız ve mutlak bir karar verme yetki ve özgürlüğünden söz edilemez. ${ }^{78}$ Çünkü velayet ve vesayet özgecil hak ve yetkilerin tanındığı bir statü ilişkisidir. ${ }^{79}$ Korunmaya ihtiyacı olduğu için velayet veya vesayet altında bulunan kişilerin nesne değil özne olduğu dikkate alınırsa veli veya vasinin korumakta yetersiz kaldığı veya keyfi davrandığı

\footnotetext{
76 Bakınız Helvacı (n 47) 113-114; Kara Kılıçarslan (n 4) 52. Ayrıca Bakınız ve karşılaştırınız Kılıçoğlu (n 25) 356.

77 Aynı yönde bakınız Cansu Kaya Kızılırmak, 'Velayet Hakkının Kapsamı Çerçevesinde Bebeklik Dönemi Aşı Uygulamalarına Rızanın Esirgenmesi’ iç Abuzer Kendigelen ve Saibe Oktay Özdemir (edr), Prof. Dr. Feyzi Necmeddin Feyzioğlu'nun Anısına Armağan (On İki Levha 2020) 465.

78 Bakınız Serozan, Medeni Hukuk (n 45) 469; Kaya Kızılırmak (n 77) 460-461.

79 Velayetin "özgecil” karakteri hakkında bakınız Rona Serozan, Çocuk Hukuku (2. Bası, Vedat 2005) 250. Öğretide velayetin daha önce ileri sürüldüğü gibi mutlak bir hak olmaktan çok sosyal bir "yüküm-hak" olarak nitelendirilmesi ve velinin ya da vasinin yetkilerini kendi kontrolü altında tutamaması, bu yetkilerin sınırlandırılması veya kaldırılması konusundaki yetkinin aile mahkemesi hâkimine veya vesayet makamına ait olması sebebiyle bu ilişkinin statü ilişkisi olarak nitelendirilmesi gerektiği kanaatindeyiz. Bakınız Serozan, Çocuk Hukuku (n 79) 250-253, 257; Bilge Öztan, Aile Hukuku (6. Bası, Turhan 2015) 1074-1079; Mustafa Dural, Tufan Öğüz ve Mustafa Alper Gümüş, Türk Özel Hukuku Cilt III Aile Hukuku (13. Bas1, Filiz 2018) 351-353; Emine Akyüz, Çocuk Hukuku Çocukların Hakları ve Korunması (3. Bası, Pegem 2013) 208-211.
} 
hallerde yasal temsil yetkisine sınırlandırma getirilerek doğrudan doğruya ayırt etme gücünden yoksun kişinin menfaatlerinin korunması gerekir. ${ }^{80}$ Bir başka ifadeyle hastalığın teşhisi, tedavisi, önlenmesi gibi doğrudan doğruya ilgilinin menfaatini korumaya yönelik bir tıbbi müdahale için haklı bir sebep olmadan onam vermekten kaçınılması halinde mahkeme tarafından koruyucu önlem alınması hususunda Türk Medeni Kanunu madde 346 yargıca hem geniş bir takdir yetkisi hem de resen harekete geçme ve önlem alma yükümlülüğü yüklemiştir. ${ }^{81}$ Çocuk Koruma Kanunu'nda da sağlık tedbiri alma konusunda çocuk yargıcına yetki tanınmışsa da bu yasanın amacının korunmaya muhtaç çocukları korumak olduğu dikkate alındığında ailesiyle yaşayan, manevi olarak terk edilmemiş bir çocuğun korunmaya muhtaç olup olmadığı hususunda tereddüt meydana gelmektedir. Oysaki Türk Medeni Kanunu madde 346'da yargıca tanınan takdir yetkisi çocuğun menfaatinin tehlikeye düştüğü her durumda durum daha ağır bir önlem almayı gerektirecek kadar kötüleşmeden önlem almaya, çocuğu ailesinin yanındayken koruyup desteklemeye yöneliktir. ${ }^{82}$

Uygulamada yenidoğanlar için tanı amacıyla topuk kanı alma işlemine ${ }^{83}$ gereksiz gördüğü için, ameliyata giren çocuğuna kan nakli yapılmasına Yehova şahidi olduğu için karşı çıkanlar yanında bilgi kirliliği ve bilimsellikle ilgisi olmayan aşı karşıtı kampanyaları baskısı altında olumsuz etkilenerek bebeklik ve çocukluk döneminde yapılması önerilen koruyucu/önleyici aşıları yaptırmaktan kaçınan ebeveynler de görülmektedir. Bu hallerde anne babalar kendi kişisel görüşleri doğrultusunda bakım vermekle yükümlü olduğu çocuklarının sağlığını tehlikeye düşürmektedir. ${ }^{84} \mathrm{Bu}$ durum söz konusu anne babayı her konuda çocuğunu ihmal eden veya istismar eden ebeveyn yapmamakla birlikte yasaya göre çocuğun bedeni üzerinde mutlak iktidar kurma ve çocuğa zarar verme riski yaratma yetkisinin anne babaya tanınmadığını vurgulamak gerekir. ${ }^{85} \mathrm{Bu}$ sebeple anne babanın kusuru olsun olmasın çocuğun menfaatlerini objektif olarak tehlikeye düşürmek çocuğun korunması için önlem alınması bakımından yeterlidir. ${ }^{86}$

Bu bağlamda bebeklik dönemi aşılarıyla ilgili olarak Anayasa Mahkemesi’nin HS Aysal Bireysel Başvuru Kararının gerekçelerine değinmek gerekir. ${ }^{87}$ Anne ve babası

80 Bakınız Kaya Kızılırmak (n 75) 461-462.

81 Serozan, Çocuk Hukuku (n 79) 292.

82 Gülçin Elçin Grassinger, Türk Medeni Kanununda Yer Alan Velayet Hükümleri Kapsamında Küçüğün Kişi Varllğının Korunması İçin Alınacak Tedbirler (On İki Levha 2009) 110-111; Dural, Öğüz ve Gümüş (n 79) 361; Akyüz (n 79 ) 257.

83 Anne babası topuk kanı alınmasına onam vermediği için hakkında sağlık tedbiri alınan çocuk adına yapılan bireysel başvuruda Anayasa Mahkemesi, yenidoğan tarama programı için gerekli yasallık ölçütünün bulunduğu gerekçesiyle hak ihlalinin bulunmadığı sonucuna varmıştır. Bakınız M. A. Bayram Başvurusu, Başvuru No. 2014/4077 (AYM, 29 Haziran 2016) RG: 26.10.2016. Bu konuda inceleme için bakınız Hasan Atilla Güngör, 'Anayasa Mahkemesi'nin Topuk Kanı Testi ve Zorunlu Aşılama Uygulamaları Hakkındaki Kararlarına İlişkin Kısa Bir Değerlendirme’ (2018) 10(100) Fasikül Hukuk Dergisi 395, 397.

${ }^{84}$ Bakınız Kaya Kızılırmak (n 77) 465-467.

85 Yücel (n 40) 270-271; Kaya Kızılırmak (n 77) 465. Aynı yönde bakınız Serozan, Çocuk Hukuku (n 79) 284. Serozan (Çocuk Hukuku (n 79) 284), bunu hakkın kötüye kullanımı olarak nitelendirmektedir.

86 Kaya Kızılırmak (n 77) 466. Üstelik bu tehlikenin ağır nitelikte olması aranmaz. Bakınız Elçin Grassinger (n 82) 108-109, 112.

${ }^{87}$ HS Aysal Başvurusu, Başvuru No. 2013/1789 (AYM, 11 November 2015) RG: 24.12.2015. 
tarafından çocuğa bebeklik dönemi aşılarının yapılmasına izin verilmemesi üzerine Bakanlık İl Müdürlüğü tarafından mahkemeye başvurularak sağlık tedbiri alınması istenmiş, mahkeme sağlık tedbiri alınmasına karar vermiştir. Bunun üzerine çocuğun babası çocuk adına zorunlu aşı uygulamasının yasal temeli olmadığı gerekçesiyle bireysel başvuruda bulunmuştur. Anayasa Mahkemesi yaptı̆̆1 değerlendirmede zorunlu aşı uygulaması varmış gibi, bir başka ifadeyle her çocuk için çocuk adına karar vermeye yetkili kişilerin onamı alınmaksızın doğrudan doğruya aşı yapılıyormuş gibi kamu sağlığının korunması için yapılabilecek müdahaleler için yasal temelin bulunması gerektiğine işaret etmiştir. ${ }^{88}$ Oysaki zorunlu olduğu ileri sürülen bir aşı uygulaması bulunmamaktadır, bunun yerine anne babası tarafından onam verilmediği için anne babanın onamının aranmaması amacıyla mahkemeye bütün çocuklar için değil münferit bir çocuk için yapılmış bir başvuru vardır. Öte yandan Mahkemenin Anayasa madde 17 ve AİHS madde 8 ile ilgili olarak yaptı̆̆ değerlendirmelerde çocuğun bedeninin anne babanın bedeninden ayrı tutulamadığ anne babadan onam alınmadan çocuğa yapılan tıbbi müdahaleyle sanki çocuğun kendi onamı alınmadan zorla çocuğa müdahalede bulunmuş gibi yorumlandığ görülmektedir. ${ }^{89}$ Oysaki çocuğun velilerine tanınan onam verme yetkisi mutlak değildir. Çocukların özerklik hakkı sadece velilerine tanınan yetkilerle değil, velileri denetlemekle ve gerektiğinde velayet yetkilerine müdahalede bulunmak hususunda kanunla idari veya yargısal makamlara tanınan yetkilerle de korunmaktadır. İnsan Hakları ve Biyotıp Sözleşmesi’nin muvafakat verme yeteneği olmayan kişilerin korunmasına ilişkin 6. maddesine göre yasal olarak müdahaleye muvafakat verme yeteneği bulunmayan küçüğe sadece kanunla belirlenen yetkili makam, kişi veya kurumun izniyle ve yalnızca onun doğrudan yararı için tıbbi müdahalede bulunulabilir. Öyleyse Anayasa madde 17 ve AİHS madde 8 hükümlerinin yorumu aracılığıyla sırf

\footnotetext{
“54. Zorunlu aşı uygulamalarının Sözleşme'nin 8. maddesi kapsamında AİHM içtihadına da konu edildiği ve Mahkemece, uygulanan tıbbi müdahalenin boyutuna bakılmaksızın söz konusu müdahalenin fiziksel bütünlük hakkına bir müdahale teşkil ettiği tespitine yer verildiği görülmektedir. Mahkemece ele alınan ve kanunilik şartını sağladığı tespit edilen müdahaleler açısından genel olarak, söz konusu uygulamanın bireyin ve toplumun sağlığını korumaya ilişkin meşru amaç nazara alınarak yapılan dengelemede, bireyin vücut bütünlüğünün korunmasına ilişkin menfaat karşısında kamu sağlığının korunması şeklindeki menfaate üstünlük tanındığı ve söz konusu müdahalelerin özel hayata saygı hakkını ihlal etmediğine hükmedildiği görülmektedir (Boffa ve diğerleri/San Marino, B. No: 26536/95, 15/1/1998, § 4; Solomakhin/Ukrayna, B. No: 24429/03, 15/3/2012, §§33-38). 55. Tıbbi müdahalelere ilişkin gerek ulusal gerek uluslararası alandaki mevzuat hükümleri rıza unsurunu temel şart olarak öngörmekte, velayet veya vesayet altındaki küçük yaştaki çocuklara veya kısıtlılara uygulanacak müdahaleler açısından da kanuni temsilcilerin rızası söz konusu tıbbi muamele sujesinin rızası yerine ikame edilmekte ve rıza şartına istisna getirilebilecek hâller genel olarak acil durumlar bağlamında tıbbi zorunluluk hâlleri ile kanunda belirtilen durumlarla sınırlandırılmaktadır $(\$ \S 15,20-26)$....57. Anayasa'nın 17. maddesinde de tıbbi zorunluluklar ve kanunda yazılı hâller dışında kişinin vücut bütünlügüne dokunulamayacağı belirtilmiştir. Söz konusu düzenlemede özel sınırlama sebepleri öngörülmemiş olmakla birlikte kanun ile düzenleme hükmüne yer verilmiş olup bu kapsamda yapılan müdahalelerin meşruluğunun denetlenmesinde, Anayasanın 13. maddesinde yer alan güvence ölçütlerinin dikkate alınması zorunludur. ... 68. Zorunlu aşı uygulaması ebeveyn tarafından reddedilen çocukların, 5395 sayılı Kanun kapsamında korunmaya muhtaç çocuk olarak değerlendirilmesi noktasında da kamu makamları ve başvurucu arasında görüş birliği bulunmamakla birlikte, esasen uygulanacak tıbbi müdahalenin türü ve kapsamı hakkında bir açıklamada bulunulmaksızın çocuğun fiziksel ve ruhsal sağlığının korunması ve tedavisi için gerekli geçici veya sürekli tıbbi bakım ve rehabilitasyonunu içerecek şekilde, genel olarak sağlık tedbirine hükmedileceğine işaret eden söz konusu düzenlemenin, somut başvuruda olduğu gibi doğan her çocuğa belirli bir yaş periyoduna bağlı olarak ve ebeveynin rızası hilafina, ilgili idarece belirlenecek olan her türlü așının tatbiki yetkisi verildiği șeklinde anlaşılması olanaklı değildir. Aksinin kabulü hâlinde uygulanacak tıbbi müdahalenin tür ve kapsamı belirsiz olacak şekilde, rıza verilmeyen müdahale türlerinin gündeme gelmesi muhtemeldir."

89 Kaya Kızılırmak da onamın velayetin anlamı ve kapsamı açısından değerlendirilmemesinin eksiklik olduğunu ifade etmektedir. Kaya Kizılırmak (n 77) 454-455.
} 
anne babanın onam göstermemesi halinde ilgilinin onamının aksine müdahalede bulunulduğu çıkarımı isabetli değildir, çünkü Türk Medeni Kanunu'nun 346. maddesine göre çocuğun menfaatlerinin tehlikeye düşmesi halinde uygun önlemleri alma hususunda hâkime bilinçli olarak geniş bir takdir yetkisi tanınmıştır. ${ }^{90}$ Böylece esasen çocuğun menfaatlerini korumada çocuk adına karar verme konusunda kanuna göre tek yetkilinin veli olmadığı, velinin yetkilerine müdahalede bulunma ve velinin yerine gerekli önlemleri alma konusunda aile mahkemesi hâkimine yetki tanındığ 1 anlaşılmaktadır. Evlat edinme bakımından kan hısımı olan anne baba küçüğe karşı özen yükümlülüğünü yeterince yerine getirmediğinde TMK madde 311/b.2 gereği mahkeme onamın aranmasından vazgeçilmesine karar vermeye yetkili sayıllırken çocuğun menfaatleri açısından çok daha önemli bir konuda mahkemenin onamın aranmasından vazgeçilmesine karar vermeye yetkili olmadığını ileri sürmek Türk Medeni Kanunu'nun sözüne ve ruhuna uygun düşmemektedir. ${ }^{91}$

Özetlemek gerekirse çocuğun özerklik hakkı çerçevesinde somut olayın koşullarına göre çocuğun yüksek yararının neyi gerektirdiğine karar verme yetkisi mutlak biçimde anne babaya tanınmamış, ikincil olarak aile mahkemesi hâkimine de tanınmıştır. ${ }^{92}$ Önemli olan husus aile mahkemesi hâkiminin somut olayın koşullarında uygulanması önerilen aşılamanın çocuğun doğrudan yararı için gerekli olup olmadığını araştırarak tespit etmesidir. ${ }^{93}$ Böyle bir durumda onam hakkına kısıtlama getirilmiş sayılamayacaktır. Çocuğun doğrudan yararının olmaması halinde velinin veya aile mahkemesi hâkiminin müdahaleye onam verme yetkisi olmayacağı için kanunla belirlenen hallerde kişiliğe müdahalede bulunulabilecektir. Velinin yetkilerini kötüye kullanabileceği her olası durum için kanun hükmü öngörmek mümkün olmadığ 1 gibi hâkimin böyle bir tedbir alamayacağını ileri sürmek yargıya tanınan yetkinin yok sayılması anlamına gelmektedir. Aşı bağlamında tartışılması gereken husus, aş1lanmayan çocuk nedeniyle sadece kamu yararının mı tehlikeye düştügü, yoksa aynı zamanda ve öncelikle kendi yararının da mı tehlikeye düşüp düşmediğidir. Aşı karşıtlığının yaygınlaştı̆̆ 1 ve bu nedenle son yıllarda kızamık salgınının yayıldığı İngiltere'de vakaların \% 80'inin aşılanmamış çocuklarda görüldüğüne ilişkin aktarılan bilgiler dikkate alındığında bulaşıcı hastalıklarla ilgili olarak aşılanmada kamu sağlı̆̆ının korunması dolaylı ve makro ölçekli bir hedeftir, öncelikli hedef bireysel

90 Elçin Grassinger (n 82) 115, 120; Dural, Öğüz ve Gümüş (n 79) 361; Kaya Kızılırmak (n 77) 467-468.

91 Aynı yönde bakınız Elçin Grassinger (n 82) 122. Akyüz, bu yönde karar verme yetkisini hâkimin anne babaya bağlayıcı nitelikte direktif verme yetkisiyle açıklamaktadır. Bakınız Akyüz (n 79) 260.

92 Aynı yönde bakınız Akyüz (n 79) 258-261; Serozan, Çocuk Hukuku (n 79), 292; Badur (n 1) 122. Serdar Özgüldür'ün ilgili karar için yazmış olduğu karşıy gerekçesi de aynı yöndedir: "Uygulamada derece mahkemelerinin, ebeveynlerin rızasının şart olduğuna dair verdiği bazı kararlar olduğu gibi; bu başvuruda olduğu gibi, çocuğun üstün yararı gözetildiğinde sağlığın korunmasında bu rızanın gerekmediği yolunda verilen kararlarında bulunduğu anlaşılmaktadır. Yargıtay 2. Hukuk Dairesi de bir kararında "Ana babanın çocuklarla ilgili karar alırken onların menfaatlerini de üstün yararlarını göz önünde tutmaları asıldır. Çocuğun yasal temsilcileri uygulanacak aşı ile ilgili aydınlatıldıkları halde, hiçbir haklı gerekçe ileri sürmeksizin buna rıza göstermiyorlarsa, çocuğun menfaatine aykırı bu tavra hukuki sonuç bağlanamaz, çocuğun üstün yararına açıkça aykırı ise rıza aranmaz." demektedir."

93 Aynı yönde bakınız Kaya Kızılırmak (n 77) 468-469. 
sağlığın korunmasıdır. ${ }^{94}$ Anayasa Mahkemesi kararına konu olayda ise kararın TMK 346 gereğince aile mahkemesi hâkimi tarafından değil Çocuk Koruma Kanunu'na göre korunmaya muhtaç çocuklar için tedbir almaya yetkili çocuk hâkimi tarafından alınması kanaatimizce isabetli olmamıştır.

\section{2. İlgilinin Doğal İradesine Rağmen Aşılama ve Tedavi}

Ayırt etme gücünden sürekli olarak yoksun kişilerin gerçek anlamda oluşturabildikleri bir iradeden söz edilemez. Söz konusu kişiler idrak ve muhakeme kabiliyetinden yoksun durumdadır, yaptıkları seçim kendi ahlaki yargıları çerçevesinde tutarlı ve akılcı olmayabileceğinden hukuk düzeni ayırt etme gücünden yoksun durumdayken gösterilen tepkilere ve ifade edilen isteklere bağlayıcılık tanımamaktadır. Buna karşın ayırt etme gücünden yoksun da olsa komada veya bitkisel yaşamda olmayan kişilerin duygusal tepkileri göz ardı edilemez. Doğal irade olarak açıklanabilecek bu duygusal tepkiler kimi zaman kişinin objektif anlamda belirlenebilecek üstün yararıyla bağdaşmayabilir. ${ }^{95}$ Ancak böyle bir halde kişiye zorla tıbbi müdahalede bulunulması ve özgürlüğünden alıkoyulabilmesi için yasayla zorla müdahalenin koşullarının düzenlenmesi ve bu hususta karar vermeye yetkili kişi veya kurumun belirli olması gereklidir. ${ }^{96}$ Belirtmek gerekir ki müdahalenin kişinin sağlığ için önemi ve ivediliği güçlendikçe doğal iradeye atfedilen önem azalır. ${ }^{97}$

Koruma amacıyla özgürlüğ̈̈n kısıtlanması tedbirinin koşulları Türk Medeni Kanunu'nun 432. maddesi ve devamındaki maddelerde düzenlenmiştir. Ísviçre Medeni Kanunu'ndan alınan bu düzenlemenin Avrupa Insan Hakları Sözleşmesi madde 5/1/e hükmü ile paralellik taşıdığı dikkat çekmektedir. Erginler için öngörüldüğ̈̈ belirtilen hükümler TMK madde 446'da yapılan gönderme hükmü sebebiyle küçükler yönünden de uygulanır. Türk Medeni Kanunu'nun 432. maddesine göre akıl hastaliğl, akıl zayıflı̆̆ ve maddede sayılan diğer sebeplerden biriyle toplum için tehlike oluşturan kişi, kişisel korunmasının başka şekilde sağlanamaması halinde tedavi, eğitim ve ıslah için elverişli bir kuruma yerleştirilir veya alıkonulabilir. Belirtmek gerekir ki Türk Medeni Kanunu'nda zorla müdahalenin koşullarının temel hak ve özgürlükleri güvence altına almaya elverişli şekilde somutlaştırılmadığl, yalnızca kuruma yerleştirmeden söz edildiği, zorla müdahalenin ölçülü sayılmasının kriterlerinin öngörülmediği anlaşılmaktadır. Yalnızca TMK madde 432/2'de kişinin çevresine getirdiği külfetin göz önünde tutulacă̆ belirtilerek ölçülülük kriterine göndermede bulunulmaktadır.

\footnotetext{
94 Bakınız Mine Kasapoğlu Turhan, ‘İdari Kolluk Yetkisi Bağlamında Zorunlu Așı Uygulaması' (2019) 9(1) Hacettepe Üniversitesi Hukuk Fakültesi Dergisi 1, 4, 21. Ayrıca bakınız İlker Belek, 'İngiltere'de Kızamık Salgını ve Aşı Karşıtlığı' (Sol Haber Portal1, 12 January 2018) <https://haber.sol.org.tr/dunya/ingilterede-kizamik-salgini-ve-asi-karsitligi-224706> Erişim Tarihi 27 Haziran 2020

95 Doğal irade kavramı hakkında ayrıntılı bilgi ve değerlendirmeler için bakınız Yücel (n 40) 87-98.

96 Psikiyatri hastalarının zorla/gönülsüz tedavi edilmelerine ilişkin farklı ülkelerdeki hukuksal süreçler hakkında karşılaştırmalı bilgi için bakınız Selin Demirdoğan ve Mustafa Solmaz, 'Psikiyatride 'Zorunlu Yatışlar”' (2019) 32(2) Adli Tıp Dergisi 84, $86 \mathrm{vd}$.

97 Bakınız Yücel (n 40) 96, 98.
} 
Oysaki İsviçre Medeni Kanunu'nda kuruma yerleştirme dışında psikolojik bir rahatsızlığın varlığı halinde onam alınmadığı halde tıbbi müdahalenin yapılabilmesinin koşulları özel olarak 434. madde ve devamındaki maddelerde açıklanmaktadır. İsviçre Medeni Kanunu'nun 434. maddesinin ilk fikrasına göre ilgilinin onamı bulunmadığında, yapılması düşünülen müdahale yapılmadığı takdirde ilgilinin sağlığında ciddi bir zarar tehdidi ortaya çıkarsa veya üçüncü kişilerin yaşamı veya beden bütünlüğü ciddi olarak zarar tehdidine maruz kalırsa, müdahaleyle ilişkili olarak ilgili ayırt etme gücünden yoksun olursa ve daha az keskin nitelikte ölçülü bir tedbirle zarar tehdidinin önüne geçilemiyorsa zorla müdahaleye başvurulabilecektir. Dolayısıyla müdahalenin ölçülü olup olmadığına müdahaleden beklenen yararlar ve sakıncalar ile müdahalede bulunulmamasının olası sakıncalarının karşılaştırılması suretiyle karar verilebilir. ${ }^{98}$ Üstelik TMK 432'de kişisel korunmanın mı toplum menfaatinin mi öncelikli tutulduğu anlaşılamazken salt zorla tıbbi müdahaleye hasredilmiş olan bu düzenlemede açıkça ilgilinin sağlığ veya beden bütünlüğü açısından zarar tehdidi doğması yeterli sayılmaktadır, her ikisi birden aranmamaktadır. Dolayısıyla Türk hukuku için de İsviçre Medeni Kanunu'ndaki düzenlemelere benzer şekilde zorla tıbbi müdahaleye özgü hükümler öngörülmesi gerekir. ${ }^{99}$ Esasen İsviçre Medeni Kanunu'ndaki söz konusu düzenlemelerin İnsan Hakları ve Biyotıp Sözleşmesi'nden kaynaklandığı anlaşılmaktadır. Sözleşmenin 7. maddesine göre "Ciddî nitelikte akıl hastallğı olan bir kişi, -gözetim, denetim ve bir makama başvurma işlemleri dahil kanunda belirtilen koruyucu şartlara bağlı olarak- sadece, böyle bir tedavi yapılmadı̆̆ takdirde sağlı̆̆ına ciddî bir zarar gelmesinin muhtemel olduğu durumlarda, muvafakatı olmaksızın, akal hastalığının tedavi edilmesini amaçlayan bir müdahaleye tâbi tutulabilir”. Sözleşmenin Türk hukuku açısından kanun hükmünde olduğu dikkate alınırsa doğrudan uygulanabilir niteliktedir. Bu noktada tedavi olarak uygulanması planlanan girişimin gerçekten kişinin yaşam kalitesini artıracak bir etkide bulunup bulunmayacağı, bir başka ifadeyle yalnızca onu adeta normalleştirme iddiasıyla baskılayıp baskılamayacağı eleştirel bir yaklaşımla sorgulanmalıdır. ${ }^{100}$

5275 sayılı Ceza ve Güvenlik Tedbirlerinin İnfazı Hakkında Kanun'un 82. maddesinde açlık grevi veya ölüm orucunda bulunan veya bu durumla ilgisiz şekilde muayene ve tedaviyi reddeden hükümlülere hangi durumda zorla tıbbi müdahalede bulunulabileceği düzenlenmektedir. Söz konusu maddenin ikinci fikrasına göre "Beslenmeyi reddederek açlık grevi veya ölüm orucunda bulunan hükümlülerden, birinci fikra gereğince alınan tedbirlere ve yapılan çalışmalara rağmen hayatî

\footnotetext{
98 Bakınız Badur (n 1) 293-300.

99 Türkiye Psikiyatri Derneği'nin 2017 yılında hazırlayarak kamuoyuna sunduğu Ruh Sağlığı Yasa Taslağı'nın "İstemsiz Tedavi ve Yatış" başlıklı 15. Maddesinde İsviçre hukukunda öngörülen düzenlemedeki esaslara paralel bir düzenleme önerisinde bulunulduğu görülmektedir. Bakınız Türkiye Psikiyatri Derneği, <https://www.psikiyatri.org.tr/ uploadFiles/2811201717434-Ruh-Sagligi-Yasa-Taslagi.pdf> Erişim Tarihi 5 Temmuz 2020; Demirdoğan ve Solmaz (n 96) 88.

100 Psikiyatrinin tedavi yöntemlerine eleştirel yaklaşım için bakınız Szasz, Deliliğin İmalatı (n 19), 12-13, 22-23.
} 
tehlikeye girdiği veya bilincinin bozulduğu hekim tarafindan belirlenenler hakkinda, isteklerine bakılmaksızın kurumda, olanak bulunmadiğ takdirde derhâl hastaneye kaldırllmak suretiyle muayene ve teşhise yönelik tıbbî araştırma, tedavi ve beslenme gibi tedbirler, sağlık ve hayatlar için tehlike oluşturmamak şartıyla uygulanır". Dolayısıyla hükümlü kendisine müdahalede bulunulmamasını istediği halde bilincinin bozulması halinde veya bilinci bozulmamakla birlikte yaşamsal tehlikenin meydana gelmesi halinde zorla müdahalede bulunulabileceği belirtilmektedir. Maddenin üçüncü fikrasında ise açlık grevi veya ölüm orucuna girmemekle birlikte sağlık sorunu olduğu halde muayene ve tedaviyi reddeden hükümlülerin sağl1k veya yaşamının ciddi tehlike içinde olması halinde yine zorla müdahalede bulunabileceği belirtilmektedir. Hükümlülere zorla müdahaleyi öngören yasal düzenlemelerde esasen hükümlünün kendi üstün yararının korunduğu iddiası söz konusudur ancak ayırt etme gücü bulunduğu halde veya ayırt etme gücünü kaybetmeden önce açıkça müdahaleyi ret beyanı olduğu halde müdahalede bulunulması özerklik hakkına ve insan onuruna aykırı düşmektedir. ${ }^{101}$ Fakat Avrupa İnsan Hakları Mahkemesi'nin konuya ilişkin vermiş olduğu kararlardaki yaklaşımı zorla beslemeye tümüyle karş1 olmak yerine usulüne, yöntemine dikkat etmek kaydıyla bunun hukuka uygun olacağ ${ }_{1}$ yönündedir. ${ }^{102}$ Burada eleştirel bir bakışla yasa koyucunun bireyin menfaatinden ziyade devletin menfaatini koruma kaygısıyla hareket ettiği ileri sürülebilir, hükümlünün yaşamak istememesinin, ruhsal sağlı̆̆ının kötüleşmesinin sebebinin cezaevi koşulları ve cezaevi yönetiminin tutum ve davranışlarının olduğu ileri sürülerek herhangi bir davanın açılmasının önü kapatılmak istenmektedir. Ancak bunun isabetli bir yöntem olmadığı açıktır, hükümlü yaşamını kaybetsin kaybetmesin cezaevinde maruz kaldığı kötü koşullardan dolayı devletin sorumlu tutulabileceği belirtilmelidir.

\section{B. Başka Bir Kişi Yararına Tıbbi Müdahalelerde}

\section{Soybağı Davalarında}

Türk Medeni Kanunu'na göre soybağının reddi davasında, sonradan evlilik yoluyla kurulan soybağına itiraz davasında, tanımanın iptali davasında veya babalık davasında davacı veya davalının kendisine düşen ispat yükü kapsamında çocuk ile erkek arasında soybağının bulunduğunu veya bulunmadığını ortaya koymak amacıyla genetik incelemeye başvurulabilmektedir. Soybağı davalarında TMK madde 284 ile mahkemeye resen araştırma yetkisi tanınmış ve yükümlülügü yüklenmiş olduğundan davacının veya davalının talebi üzerine mahkeme tarafından diğer taraftan biyolojik örnek alınmasına karar verebilecektir. Türk Medeni Kanunu'nun 284. maddesinde

\footnotetext{
101 Aynı yönde bakınız Serozan, Medeni Hukuk (n 45) 465. İnsan onurunun temeline ahlaki otonomiyi yerleştiren Kantçı düşünce ve insan onuru hakkında ayrıntılı tartışma için bakınız Metin (n 13) 7 vd

102 Bakınız Ersan Şen ve Fatma Betül Bodur, 'Devletin Yaşam Hakkını Koruma Zorunluluğu' (2017) 12(132) Terazi Hukuk Dergisi 125, 130-131.
} 
ilgililerin kendilerinden biyolojik örnek alınmasına ve bu örnek üzerinde inceleme yapılmasına onam vermeye zorlanıp zorlanamayacağ 1 hakkında bir hüküm öngörülmektedir. Buna göre "Taraflar ve üçüncü kiş̧iler, soybağının belirlenmesinde zorunlu olan ve sağllklar yönünden tehlike yaratmayan araştırma ve incelemelere rıza göstermekle yükümlüdürler. Daval,, hakimin öngördüğ̈̈ araştırma ve incelemeye rıza göstermezse, hakim, durum ve koşullara göre bundan beklenen sonucu, onun aleyhine doğmuş sayabilir." Dolayısıyla soybağının tespiti amacıyla kişinin sağlığ için tehlike yaratmayacak olsa bile bir kişinin beden bütünlüğüne zorla müdahale edilemeyecek, onam vermekten kaçınma hali soybağı davasında onam vermeyen kişinin aleyhine yorumlanacaktır.

Öte yandan 12.01.2011 tarihli Hukuk Muhakemeleri Kanunu'nun 292. maddesine göre "(1) Uyuşmazlığın çözümü bakımından zorunlu ve bilimsel verilere uygun olmak, ayrıca sağllk yönünden bir tehlike oluşturmamak şartıyla, herkes, soybağının tespiti amacıyla vücudundan kan veya doku alınmasina katlanmak zorundadır. Haklı bir sebep olmaksızın bu zorunluluğa uyulmaması hâlinde, hâkim incelemenin zor kullanılarak yapılmasına karar verir. (2) Üçüncü kişi tanıklıktan çekinme hakkı bulunduğunu ileri sürerek bu yükümlülükten kaçınamaz." Türk Medeni Kanunu'nun aksine Hukuk Muhakemeleri Kanunu'nda hâkime incelemenin zor kullanarak yapılmasına karar verme yetkisinin tanınmış olması hangi düzenlemenin esas alınacağı tartışmasını beraberinde getirmiştir. ${ }^{103}$ Sonraki kanun hükmü HMK'de öngörülmüş olsa da öğretide haklı olarak usul kanunuyla maddi hukuk düzenlemesinin değiştirilemeyeceği, temel hak ve özgürlüklere yönelik müdahalelerin maddi hukuk hükümleri içeren bir kanunla öngörülebileceği ileri sürülmektedir. ${ }^{104}$ Öte yandan öğretide bir diğer görüşe göre usul hukukuyla ilgili hükümlerin TMK'de yer alabildiği ve bu hükmün yargılama hukukuna ilişkin olduğu dikkate alındığında sonraki kanun hükmü olan HMK madde 292'nin TMK madde 284 karşısında üstün tutulması gerekmektedir. ${ }^{105}$ Yargitay Hukuk Genel Kurulu, 2018 yılında verdiği bir bozma kararında sonraki kanun olan HMK madde 292'nin TMK madde 284 ile karşılaştırıldığında özel hüküm içerdiği gerekçesiyle HMK madde 292'nin uygulanması gerektiği sonucuna varmıştır. ${ }^{106} \mathrm{HMK}$ madde 292'nin TMK madde 284 karşısında üstün tutulması gerektiği sonucuna varılsa bile Aksoy Dursun'un işaret ettiği üzere ilgili düzenleme kaynak kanun hükmü olan Alman ZPO § 372a'nın

103 HMK'deki söz konusu düzenlemenin İsviçre Medeni Usul Kanunu'ndan alındığı anlaşılmaktadır. Bakınız Özlem Tüzüner, Adli Genetik ve Tıbbi Biyoloji Bilimlerinin Soybağı Hukukuna Etkisi (Filiz 2016) 16-17.

104 Dural, Ögüz ve Gümüş (n 79) 269-270. Aksi görüş için bakınız Özbilen (n 32) 330; Kirkit (n 1) 175-176; Cem Akbıyık ve Gülşah Sinem Aydın, 'Hukuk Muhakemeleri Kanunu M.292 Uyarınca Kişilerden Soybağı Tespiti Amacıyla Zor Kullanılarak Kan veya Doku Alınmasının Kişilik Hakkını İhlal Edip Etmediği Sorunu’ (2014) 13(1) İstanbul Kültür Üniversitesi Hukuk Fakültesi Dergisi 7, 21-22.

105 Sanem Aksoy Dursun, 'Soybağının Belirlenmesi Bakımından MK m. 284 ve HMK m. 292'nin Değerlendirilmesi' (2012) 8(95-96) Kazanc1 Hakemli Hukuk Dergisi 109, 121.

106 Yargitay HGK, 1927/1471, 18.10.2018, <https://karararama.yargitay.gov.tr/YargitayBilgiBankasiIstemciWeb/> Erişim Tarihi 15 November 2020. 
düzenleme tarzı ile birlikte değerlendirildiğinde tanıklığa ilişkindir. ${ }^{107} \mathrm{Bu}$ nedenle muayeneye katlanma yükümlülüğü davanın taraflarına değil, tanık sıfatını taşıyan üçüncü kişilere yönelik olmalıdır. Öte yandan hükmün uygulanma biçimi kişilik hakkına ölçüsüz bir şekilde saldırıda bulunulmasına elverişli olduğu için hükmün amacına uygun olarak sinırlandırılarak uygulanması yerinde olacaktır. ${ }^{108}$

Öte yandan İnsan Hakları ve Biyotıp Sözleşmesi’nin 26. maddesinde öngörülen kısıtlama sebepleri arasında soybağı menfaatiyle ilgili olarak yalnızca "başkalarının hak ve hürriyetlerinin korunması" sebebine dayanılabilirse de aynı maddeye göre kanunda belirtilen ve demokratik bir toplumda gerekli olanlar dişında kısıtlama konulamayacaktır. Gerçekten Fransız Medeni Kanunu'na göre insanın genetik karakterinin incelenmesinin yalnızca tıbbi veya bilimsel araştırma amacıyla gerçekleştirilebileceği, soybağının kurulması amacıyla hâkim tarafından genetik inceleme yapılmasına karar verilse de ilgilinin onamının önceden ve açıkça alınmasının zorunlu olduğu belirtilmektedir. ${ }^{109} \mathrm{Bu}$ bakımdan onam vermekten kaçınan davacı veya davalı aleyhine olmak üzere hâkimin var olan delilleri takdir etmesi suretiyle soybağını tespit etmesi ve böylece ilgililerin soybağına ilişkin menfaatleri korunması mümkün olduğu halde kişilerin beden bütünlüğünün onamları olmadığı halde zorla müdahalede bulunulması gereğinden fazla, bir başka deyişle ölçüsüz bir müdahale sayılacaktır. ${ }^{110}$ Anayasa madde 90/5 gereği usulünce yürürlüğe konulmuş ve temel hak ve özgürlüklere ilişkin uluslararası antlaşma hükümleri kanun hükümleriyle çatıştığında uluslararası antlaşma hükümleri üstün tutulur, bu nedenle HMK madde 292'de öngörülen zorla müdahale hükmünün uygulanması Anayasaya aykırı düşer.

\section{Başkalarının Tedavisi İçin Biyolojik Madde Alınmasında}

Bir kimsenin başkasının sağlığı için kendi bedeninden biyolojik madde ${ }^{111}$ alınmasına vereceği onam hakkı kişiye sıkı sıkıya bağlı olup onamın her aşamada geri alınması mümkün olduğu gibi bundan vazgeçtiği için herhangi bir yaptırıma tabi tutulamaz. ${ }^{112}$ $\mathrm{Bu}$ husus Türk Medeni Kanunu'nun 23. maddesinin üçüncü fikrasında şöyle açıklanmaktadır: "Yazılı rıza üzerine insan kökenli biyolojik maddelerin alınması, aşılanması ve nakli mümkündür. Ancak, biyolojik madde verme borcu altına girmiş olandan edimini yerine getirmesi istenemez; maddi ve manevi tazminat isteminde bulunulamaz." Biyolojik madde verme borcu altına girmek bu madde bağlamında

\footnotetext{
$\overline{107 \text { Aksoy Dursun (n 105) }}$ 118-119.

108 Aksoy Dursun (n 105) 120-122.

109 Tüzüner (n 103) 14, 22-23.

110 Aynı yönde bakınız Badur (n 1) 266. Tüzüner, mutlak gerçekliğin tespitini daha önemli görerek ciddi şüphenin varlığı halinde orantılılık ilkesi doğrultusunda zorla müdahalede bulunabileceği kanaatindedir. Bakınız Tüzüner (n 103) 21. Benzer şekilde bakınız Akbıyık ve Aydın (n 104) 25-27.

111 İnsan kökenli biyolojik madde kavramının anlamı, kapsamı ve niteliği hakkında ayrıntılı bilgi için bakınız Özbilen (n 32) 8 $\mathrm{vd}$

112 Bakınız Serozan, Medeni Hukuk (n 45) 460; Dural ve Öğüz (n 25) 117-118.
} 
başkasına nakledilmek veya bilimsel araştırmada kullanılmak üzere verme borcu anlamında kullanılmaktadır. Kişinin başkasının yararı için kendi canlı bedeniyle fedakârlığa katlanmaya zorlanması kabul edilebilir değildir. ${ }^{113}$ Etik temelleri açısından kişinin canlı verici olarak kendi bedenine araç olarak davrandığg belirtilmektedir ${ }^{114}$, bu nedenledir ki bir başkası değil kişinin kendisi bedeninin başkasının yararına araç haline gelmesine izin vermelidir. Anayasa madde 35 gereğince mülkiyet hakkının kullanımının toplum yararıyla sınırlandırılması karşısında kişiler malvarlıklarıyla fedakârlığa katlanmaya zorlanabilir ise de bedeniyle buna katlanmaya zorlamak liberal ve demokratik hukuk düzeninin gerekleriyle bağdaşmamaktadır. ${ }^{115} \mathrm{Bu}$ noktada hastalık taşıyan birinin başkalarının yararı için özgürlüğünden alıkonulması veya gerektiğinde tedaviye zorlanması ile başkaları için tehlike oluşturmayan birinin başkasının menfaati için tıbbi müdahaleye ve dahası biyolojik madde bağışlamaya zorlanması aynı kefeye koyulamaz. Hukuka aykırı eylemde bulunan kişilerin dahi yalnızca malvarlıklarıyla sorumlu tutulabileceği ilkesi karşısında hiçbir kişinin hakkını ihlal etmeyen bir kimsenin sırf biyolojik madde bağışlamaya elverişli fiziksel durumda olması sebebiyle bedeniyle fedakârlık yapmaya tabi tutulması kabul edilemez. Organ ve Doku Alınması, Saklanması, Aşılanması ve Nakli Hakkında Kanun canlı vericiden alınacak her tür organ ve doku için açıkça ilgilinin onamını aramaktadır ve bu kuralın hiçbir istisnası yoktur. Kan ve Kan Ürünleri Kanunu'nun 3/1/b hükmüne göre kan, kan bileşenleri ve ürünlerinin temininde karşılıksız ve gönüllü bağış esastır. ${ }^{116} \mathrm{Bu}$ bakımdan COVID-19 salgınında hastalanan kişilerin tedavisi için bu hastalığı atlatmış kişilerin plazma bağışına zorlanması düşünülemez. İnsan Hakları ve Biyotıp Sözleşmesi’nin 26. maddesinin ikinci fikrasında da organ ve doku bağışına ilişkin temel hak ve özgürlüklerin başka bir kişinin veya kamunun yararı gerekçesiyle kısıtlanamayacağı açıkça ifade edilmektedir. Sözleşmenin hiçbir hükmünde kan ve kan ürünleri bağışına değinilmemekle birlikte benzer şekilde başka birinin hayatının korunması için onam hakkına ilişkin koruyucu hükümlere kısıtlama getirilemeyeceği sonucuna varmak Sözleşmenin ruhuna uygun düşer.

Biyolojik madde bağışına ilişkin onam açıklaması mutlak nitelikte kişiye sıkı sıkıya bağlı olup hiçbir surette yasal temsilcinin buna karar vermesi kabul edilemez. Çünkü bir kimsenin sahip olduğu kişiye sıkı sıkıya bağlı hakların yasal temsilci

113 Aynı yönde bakınız Özbilen (n 32) 320-321; Kalkan Oğuztürk (n 13) 121; Gürbüz (n 13) 89; Kirkit (n 1) 187; Kara Kılıçarslan, (n 4) 64-65, 75. Öğretide yalnızca kadavradan organ alımı için rutin veya isteğe bakılmaksızın organ alımı yoluna başvurulması yönünde görüşler mevcut olup canlı vericiden başkasına nakil için organ alımı daima onama dayanır. Bakınız Metin (n 13) 262-263; Özlem Koçak Süren, 'Organ ve Doku Naklinin Yasal ve Etik Açıdan İncelenmesi' (2007) 73 TBB Dergisi 174, 182-183.

114 Bakınız Gürbüz (n 13) 87.

115 Serozan (Medeni Hukuk (n 45) 465) bunu sosyal kişilik ihlali bağlamında değerlendirerek kişinin irade özerkliğine müdahale olarak nitelendirmektedir.

116 Bazı ülkelerde paralı donör sisteminin olduğu belirtilse de bu sistem onamın aranmadığı anlamına gelmemektedir, gönüllülükten farklı olarak karşılıksız değildir. Bu konuda bakınız Yeşim Işı1 Ülman, 'Kan ve Kan Ürünlerinin Transfüzyonu ve Tibbi Etik' (1998) 20 Damla Kan Merkezleri ve Transfüzyon Derneği Bülteni 2, <http://kmtd.org.tr/damla/20.pdf> Erişim Tarihi 5 Temmuz 2020. 
tarafından ayırt etme gücünden yoksunluk halinde kullanımı salt o kişinin kendi menfaatlerinin korunabilmesi uğruna mümkün ve meşru say1lmaktadır. ${ }^{117}$ Nitekim 2238 say1lı Organ ve Doku Alınması, Saklanması, Aşılanması ve Nakli Hakkında Kanun'un 5. maddesine göre 18 yaşını doldurmamış ve ayırt etme gücü bulunmayan kişilerden sağlığında organ ve doku alınması yasaktır. Türk hukukunda bu hususta yenilenebilir ve yenilenemeyen doku ayrımı yapılmadan yasak getirilmesi yasal temsil yetkisinin küçük ve kısıtlı kişilerin menfaatine olmadığı halde salt başkasının yararı için bir işlem yapılmasını engellemeyi hedeflemektedir, bir başka ifadeyle yasal temsil yetkisinin istismarının önüne geçmektedir. ${ }^{118}$ Buna karşılık İnsan Hakları ve Biyotıp Sözleşmesi'nin 20. maddesinin ikinci fikrasına göre istisnai olarak muvafakat verme yeteneği olmayan bir kimseden yenilenebilir dokuların alınmasına, muvafakat verme yeteneği bulunan uygun bir vericinin bulunmaması, alıcı şahsın, vericinin erkek veya kız kardeşi olması, bağışın, alıcı bakımından hayat kurtarıcı olma beklentisinin bulunmas1, 6'nc1 Maddenin 2'nci ve 3'üncü paragraflarında koşul olarak aranan yetkinin, kanuna uygun olarak ve yetkili kurum tarafindan onaylanarak, özel olarak ve yazılı şekilde verilmiş olması ve en önemlisi de muhtemel vericinin itirazda bulunmaması koşuluyla izin verilebilir. Söz konusu düzenlemeye Türkiye tarafindan çekince koyulmuştur. ${ }^{119}$ Esasen Sözleşmenin 27. maddesine göre Sözleşmenin hiçbir hükmü taraf devletlerin Sözleşme hükümlerinden daha kapsamlı koruma önlemleri almalarını kısıtlayacak veya engelleyecek şekilde yorumlanamaz, bir başka ifadeyle Sözleşmenin insan haklarının korunmasında asgari bir standart getirdiği belirtilmektedir. Öte yandan Sözleşmede yenilenebilir dokunun bağışına izin veren düzenlemenin doğal iradeye öncelik ve önem verdiği dikkat çekmektedir. Ayırt etme gücü bulunmasa dahi vericinin bağışa yönelik itirazının olmaması bağışın vazgeçilmez koşuludur. Bu husus da yasal temsilcinin doğrudan doğruya ilgili adına bağışa karar veremeyeceğini açıklamaktadır. Zira burada ehliyetsiz kişinin kendi yararının korunması gerekçesinden söz edilememektedir. ${ }^{120}$

\footnotetext{
17 Ayırt etme gücüne sahip kısıtlıların organ bağışlayabilmesinin önünde bir engel yoktur. Dural ve Öğüz (n 25) 115. Ayrıca bakınız ve karşılaştırınız Özbilen (n 32) 279-281.

118 Zihinsel engeli bulunan kişilerin bedeninden başkasının yararı için organ alınması konusu bir yana anensefalik bebek olarak adlandırılan ömrü çok kısıtlı değerlendirilen, gelişimini tamamlayamamış bebeklerden hayattayken organ ve doku alınması konusundaki etik tartışma için bakınız Gürbüz (n 13) 91-93.

119 Uygulamada yenidoğan bebeklerin kordon kanından kök hücre alınarak başkasına nakil işlemi gerçekleştirilmektedir, bunu mümkün kılan husus kök hücrenin organ ve doku niteliğinde olmamasıdır.

120 Ehliyetsiz kişinin kendi yararı için onun doğal iradesine aykırı müdahalelerde bulunulmasının meşru olduğuna ilişkin açılamalar için bakınız Kalkan Oğuztürk (n 13) 120.
} 


\section{Onam Hakkının Sınırı Olarak Üstün Kamu Yararı ${ }^{121}$}

\section{A. Şiddetle Mücadele Amacına ${ }^{122}$ Yönelik Tıbbi Müdahaleler}

Ev içi şiddet ${ }^{123}$ ve cinsiyet temelli şiddet özel değil kamusal bir meseledir. Esasen şiddet ister özel alanda ister kamusal alanda gerçekleşsin, ister özel yaşamın paylaşıldığ1 birine yönelik ister herhangi birine yönelik işlensin her durumda şiddet yalnızca mağdurunun kişiliğini ihlal etmekle kalmaz, toplum düzenini tehdit eder. Şiddetle mücadele edilmemesi, bir başka deyişle bireylerin şiddet tehlikesine karşı korunmaması, şiddeti besleyen faktörlerin ortadan kaldırılmaması veya şiddetin yaptırımsız bırakılması, şiddet uygulayanlara cesaret verecek ve şiddetin kuşaklararası aktarımına, toplumda salgın gibi yayılmasına yol açacaktır. Kamusal bir mesele olduğu içindir ki şiddet eylemleri karşısında soruşturma veya kovuşturmanın, şiddet tehlikesine karşı bireyi koruyucu önlemler almanın mağdurun şikayetine veya koruma talebinde bulunmasına bağlı olmaması gerekir. Ev içi şiddet ve cinsiyet temelli şiddette toplumsal cinsiyet normları sebebiyle mağdurun hukuk düzeninin kendisine tanıdığı hukuksal yollara başvurmakta, haklarını kullanmakta ve şiddete karşı direnmekte baskı altında kalarak zorlandığı bilinen bir gerçektir. $\mathrm{Bu}$ nedenle özel alan şiddetine ve cinsiyet temelli şiddete karşı mücadelenin bu şiddetin özel nitelikleri dikkate alınarak yürütülmesi bir zorunluluktur. Bu bağlamda gözetilmesi gereken ilkelerden biri mağdurun şikayette bulunmaya veya tanıklık yapmaya zorlanmaması, bir diğeri de şiddetle mücadele sürecinde mağdurun ikincil örselenmesine, bir başka ifadeyle şiddet sonucunda yaşadığ travma nedeniyle bunu izleyen travmalara sebebiyet verilmemesidir.

Türkiye'nin ilk imzacısı ve ilk onaylayan ülke olduğu Kadınlara Yönelik Şiddet ve Ev İçi Şiddetin Önlenmesi ve Bunlarla Mücadeleye İlişkin Avrupa Konseyi Sözleşmesi'nde şiddetle mücadelenin bütüncül yaklaşımı gerektirdiği fikrine dayalı olarak taraf devletlerin yerine getirmesi gereken yükümlülükler ayrıntılı olarak açıklanmaktadır. ${ }^{124}$ Sözleşmenin 16. Maddesine göre ileride meydana gelecek şiddet olaylarını önleme ve şiddete dayalı davranış kalıplarını değiştirmek için ev

\footnotetext{
121 Öğretide üstün kamu yararının olduğu iddia edilen durumlar için kanunun verdiği yetkinin kullanımı hukuka uygunluk sebebinin söz konusu olduğu belirtilmektedir. Bakınız Helvacı (n 47) 115; Özbilen (n 32) 321; Kirkit (n 1) 158-159. Kanaatimizce kanunun verdiği yetkinin kullanımı çok daha geniş kapsamlıdır ve onamın bertaraf edilmediği yani onama dayanılan hallerde de müdahalenin hukuka uygunluğu için aranmaktadır. Ayrıca bu görüşün temelinde bu hallerin başlı başına kanun hükümlerinde düzenlenmesinin bulunduğu söylenebilir, ancak kanun hükümleriyle ayrı ayrı düzenlenmesinin sebebi ayrı bir hukuka uygunluk sebebi tesis etmek değil, temel hak ve özgürlüklerin sınırlandırılmasında yasallık koşulunun gereğini yerine getirmektir.

122 Şiddet dışında başka suçlarla mücadele amacına yönelik kamusal yetki kullanımı aracılığıyla tıbbi müdahaleler de üstün kamu yararına dayanmaktadır. Çalışmada diğer suçlarla mücadeleye dönük müdahaleler incelenmemiş, bireylerin yaşamında ve toplum vicdanındaki etkisinin önemi sebebiyle şiddetle mücadeleye yer verilmiştir.

${ }^{123}$ İstanbul Sözleşmesi'nin resmi çevirisinde her ne kadar "aile içi şiddet" ifadesi kullanılsa da 6284 sayılı Ailenin Korunmas ve Kadına Karșı Șiddetin Önlenmesine Dair Kanun'un 2. maddesinde "aile içi șiddet" değil, "ev içi șiddet" ifadesi kullanılmaktadır.

124 Sözleşme metni ve Sözleşmeyi onaylayan ülkeler için bakınız < https://www.coe.int/en/web/conventions/full-list/-/ conventions/treaty/210> Erişim Tarihi 7 Temmuz 2020.
} 
içi şiddet girişiminde bulunanlar ve cinsel suç işleyenler için eğitim programları düzenlenmesini veya desteklenmesini mümkün kılacak yasal veya diğer tedbirlerin alınması gerekmektedir. İstanbul Sözleşmesi olarak anılan söz konusu Sözleşme hükümlerinden örnek alınarak kabul edilmiş olan 6284 sayılı Ailenin Korunması ve Kadına Karşı Şiddetin Önlenmesine Dair Kanun'un 5/1/h hükmüne göre aile mahkemesi hâkimine şiddet failinin alkol veya uyuşturucu ya da uyarıcı madde bağımlılı̆̆ının olması halinde hastaneye yatmak dahil muayene ve tedavisinin sağlanmasına karar verme yetkisi tanınmaktadır. Aynı fıkranın (1) bendine göre ise şiddet failinin genel olarak bir sağlık kuruluşuna muayene ve tedavi için başvurması ve tedavisinin sağlanması hususunda aile mahkemesi hâkimine önleyici tedbir alma yetkisi tanınmaktadır. Söz konusu düzenlemeler doğrultusunda şiddet failinin hastaneye gitmesi ve muayene ve tedavisi konusunda karar alınabilmesi, şiddet failine hangi koşulla zorla tedavi yapılıp yapılamayacağı konusunda yeterli açıklık sağlamamaktadır. ${ }^{125} \mathrm{Bu}$ noktada İnsan Hakları ve Biyotıp Sözleşmesi ile Avrupa İnsan Hakları Sözleşmesi’nde öngörülen ilkeler doğrultusunda başkaları için yarattığı tehlike başka şekilde önlenemiyorsa üstün kamu yararı gereğince öngörülen yasal düzenlemeye dayanarak ve ölçülülük ilkesi doğrultusunda bu kişilerin tedaviye zorlanabilecekleri sonucuna varılabilir.

Cinsel şiddetle mücadelede şiddetin yaptırımsız kalmaması ve dolayısıyla etkin soruşturma ve kovuşturma yükümlülüklerinin yerine getirilmesi bağlamında ceza yargılaması hukukunda tanınan resen araştırma ve delil toplanması yetkisine dayanarak şüpheli/sanık bedeni ile mağdur bedeninde muayene yapılması ve örnek alınması için ilgililerin zorlanması insan hakları yönünden çeşitli sorunları beraberinde getirmektedir. ${ }^{126}$ Ceza Muhakemesi Kanunu'nun 75/4 hükmü gereği şüpheli/sanık bedeninde cinsel organlarda veya anüs bölgesinde yapılması düşünülen muayenenin suçun işlenmesinden bir süre sonra yapılmasının bir yararı olmayacağından ${ }^{127}$ ötürü gerçeğe ulaşma konusunda yararı olmayacağı öngörüldüğü halde kişinin böyle bir müdahaleye zorlanması onur kırıcı bir muameleden başka bir anlam taşımayacak ve ölçüsüz bir müdahale oluşturacaktır. ${ }^{128}$ Tibbi bilgi ve yöntemin toplum açısından tehlike oluşturan kişilerin disiplin altına alınması amacıyla kullanılmasından kaçınılmalıdır.

Uygulamada sıklıkla mağdurun bedeninde cinsel organlarda muayeneye başvurarak delil toplama yoluna başvurulmaktadır. Ceza Muhakemesi Kanunu'nun 76. maddesine göre, mağdurun onamının olmadığı hallerde, mağdurun bedeni

\footnotetext{
125 Söz konusu muğlaklığın kişilik hakkı bakımından oluşturduğu tehdide ilişkin eleştiri için bakınız Badur (n 1) 306.

126 İnsan bedeninden alınan örnek türleri ve alınma usulleri hakkında ayrıntılı bilgi için bakınız Kızılarslan (n 16) 120-129.

127 Cinsel saldırı olaylarında saldırganın ilk 24-48 saat içinde muayenesinin çok önemli olduğu belirtilmektedir. Bakınız Kizılarslan (n 16) 171.

128 Aynı yönde bakınız Kızılarslan (n 16) 232. Beden muayenesinin işkence ve kötü muamele yasağıyla ilişkisi hakkında bakınız Kızılarslan (n 16) 63 vd
} 
üzerinde dış veya iç beden muayenesi yapılabilmesi veya mağdurun bedeninden biyolojik örnek alınabilmesi Cumhuriyet Savcısının istemiyle ya da resen hâkim tarafindan, gecikmesinde sakınca olduğu takdirde Cumhuriyet savcısı tarafından karar verilebilir. Mağdurun bedeninde dış muayene veya psikolojik muayenenin insan onuruyla bağdaşmayan bir muamelede bulunmaksızın ve mağdurun beden bütünlüğünü bozmaksızın yapılması hususunda karar alınması varılacak amaçla karşılaştırıldığında ölçülü sayılabilirse de mağdurun bedeninde iç muayene açısından aynı sonuca varmak mümkün değildir. Dış muayene veya psikolojik muayenede de kişiye zor kullanılmasının insan onuruyla bağdaşmayacağ 1 belirtilmelidir. ${ }^{129}$

Cinsel saldırı veya cinsel istismar mağduru kişinin ancak invaziv (girişimsel $=$ beden bütünlüğünün bozulması) yolla gerçekleştirilebilen ${ }^{130}$ jinekolojik muayeneye onamı olmadığı halde hâkim veya savcı kararıyla muayene edilmesi cinsel saldırının tekrarlanması ve dolayısıyla ikincil bir örselenmenin gerçekleşmesi anlamına gelir. ${ }^{131}$ Cinsel şiddetin cezasız bırakılmayarak adaletin tesis edilmesi amacıyla başvurulan yöntem yeni bir şiddet yaratmakta ve dolayısıyla şiddetle mücadelede gözetilecek ilkeleri ihlal etmektedir. Nitekim İstanbul Sözleşmesi'nin 18. maddesinde taraf devletlerce alınacak tedbirlerin ikincil mağduriyete (travmaya) ${ }^{132}$ yol açmaması gerektiği belirtilmektedir. Cinsel istismar mağduru bir çocuğun jinekolojik muayeneye onam vermemesi sebebiyle çocuğu zorla muayene etmeyen adli tabip aleyhine ceza davası açılmışsa da beraat kararı verilmiştir. ${ }^{133}$

\section{B. Kamu Güvenliğinin Korunması Amacına Yönelik Tıbbi Müdahaleler}

Eylemleri toplum düzeni ve güvenliği için tehlike oluşturan veya toplum düzenine zarar veren psikiyatrik hastalık tanısı almış olan kişilere yönelik olarak kendi yararları yanında özellikle kamunun yararı için zorunlu tedavi önlemlerine

129 'Yaşı Küçük Kızlara Bekaret Testi Yapmadığı İçin Yargılandı: İşte Karar' (Cumhuriyet, 12 December 2019) <https://www. cumhuriyet.com.tr/haber/yasi-kucuk-kizlara-bekaret-testi-yapmadigi-icin-yargilandi-iste-karar-1707849> Erişim Tarihi 9 Haziran 2020: "Hasta kabul etmediği sürece hekim muayenesinin doğru olmadığını söyleyen Altun, "Bize gönderilen insanların muayeneleri, gerek adli gerekçelerle olsun gerek kendilerinin başvurduğu tıbbi nedenler olsun mutlaka kişinin iznine bağlıdır. Yargı mekanizması içerisinde, gönderilen hastanın muayene edilmesi zorunlu gibi bir algı var. Öyle bir şey yok. Hekim olarak hasta muayeneyi kabul etmediği takdirde zorlamak, hastaya ruhsal yönden zarar vermektir. Sonuçta bu ilk yargılanmam değil, suçlu olmadığım bir kez daha ortaya çıktı ve bir kez daha beraat ettim. Yaptığım uygulama, iyi hekimlik uygulaması olarak bir kez daha ortaya çıkmış oldu" dedi”.

130 Kizılarslan (n 16) 130, 152-155.

131 Aynı yönde bakınız Pervin Aksoy İpekcioğlu, 'Vücuttan Örnek Alma İşleminin Hukuki Niteliği ve Anayasaya Uygunluğu' (2013) 19(2) Marmara Üniversitesi Hukuk Fakültesi Hukuk Araştırmaları Dergisi (Prof. Dr. Nur Centel’e Armağan) 1157, 1172; Kızılarslan (n 16) 211, 217-218. Özbilen ((n32) 334-335), bu riske rağmen sanığın mağdur üzerinde bask1 kurmuş olma olasılı̆̆1 sebebiyle mağdurun muayeneye zorlanmasını makul karşılamaktadır. Bu görüşe katılmak mümkün değildir, mağdurun iradesinin özgür olmasını temin etmek devletin yükümlülüğ̈̈ndedir, devlet bu yükümlülüğünden mağduru muayeneye zorlayarak kurtulamamalıdır.

132 Bakınız Kızılarslan (n 16) 168, 211. Çocuk dostu adli muayenede ikincil travmanın önüne geçilmesi hakkında Bakınız Kizilarslan (n 16) 169.

$133<$ https://www.ttb.org.tr/haber_goster.php?Guid=4d5d7458-1cd0-11ea-a683-c8b1208951f8> Erişim Tarihi 9 Haziran 2020; 'Yaşı Küçük Kızlara Bekaret Testi Yapmadığı İçin Yargılandı: İşte Karar' (Cumhuriyet, 12 December 2019) <https://www. cumhuriyet.com.tr/haber/yasi-kucuk-kizlara-bekaret-testi-yapmadigi-icin-yargilandi-iste-karar-1707849> Erişim Tarihi 9 Haziran 2020. 
başvurulabilmektedir. $\mathrm{Bu}$ husustaki düzenlemeler suç işleyenler için alınacak tedbirler ve suç işlemeyenler için alınacak tedbirler olmak üzere iki ayrı bağlamda değerlendirilebilir. Suç işleyenler için oluşturulan mimari alanlar olan cezaevleri ile toplum için tehlikeli görülen kişiler için oluşturulan mimari alanlar olan hastanelerin benzerliği mimarinin "kamu hijyeni" amacıyla bir araç olarak kullanıldığını göstermektedir. ${ }^{134}$

Türk Ceza Kanunu'nun 57. maddesinin ilk ve ikinci fikralarına göre “(1) Fiili işlediği sırada akıl hastası olan kişi hakkında, koruma ve tedavi amaçlı olarak güvenlik tedbirine hükmedilir. Hakkında güvenlik tedbirine hükmedilen akıl hastalarl, yüksek güvenlikli sağlık kurumlarında koruma ve tedavi altına alınırlar. (2) Hakkında güvenlik tedbirine hükmedilmiş olan akıl hastasl, yerleştirildiği kurumun sağllk kurulunca düzenlenen raporda toplum açısından tehlikeliliğinin ortadan kalktığının veya önemli ölçüde azaldığının belirtilmesi üzerine mahkeme veya hakim kararıyla serbest bırakılabilir." Düzenlemede belirtildiği üzere tedaviye zorlama beden bütünlüğünün dokunulmazlığına özel nitelikli bir müdahale oluşturduğu için ölçülülük ilkesi gereğince toplum açısından tehlikeliliğinin ortadan kalkması veya önemli ölçüde azalması halinde tedaviye zorlama önlemine son verilebilecektir. Benzer şekilde söz konusu yasanın aynı maddesinin son fikrasına göre "Suç işleyen alkol ya da uyuşturucu veya uyarıcı madde bağımlısı kişilerin, güvenlik tedbiri olarak, alkol ya da uyuşturucu veya uyarıcı madde bağımlılarına özgü sağllk kuruluşunda tedavi altına alınmasına karar verilir. Bu kişilerin tedavisi, alkol ya da uyuşturucu veya uyarıcı madde bağımlılı̆̆ından kurtulmalarına kadar devam eder. Bu kişiler, yerleştirildiği kurumun să̆llk kurulunca bu yönde düzenlenecek rapor üzerine mahkeme veya hakim karariyla serbest birakılabilir."

Avrupa İnsan Hakları Sözleşmesi’nin 5/1/e hükmünden hareketle sevk edildiği anlaşılan Türk Medeni Kanunu'nun 432. maddesinin ilk fikrasının ilk cümlesine göre "Akıl hastalığı, akll zayıfllğı, alkol veya uyuşturucu madde bağımlıllğgl, ăğı tehlike arzeden bulaşıcı hastalık veya serserilik ${ }^{135}$ sebeplerinden biriyle toplum için tehlike oluşturan her ergin kişi, kişisel korunmasının başka şekilde sağlanamaması halinde, tedavisi, eğitimi veya uslahı için elveriş̧li bir kuruma yerleştirilir veya alıkonulabilir". Düzenlemenin kaleme alınma biçiminden tedaviye zorlanmanın koşullarının yeterli açıklıkta ve ayrıntıyla ortaya koyulmadığı görülmektedir. Bununla birlikte TMK madde 432'nin ikinci ve üçüncü fikralarında öngörülen hükümler düzenlemenin

\footnotetext{
34 Lukasz Stanek, 'Biopolitics of Scale: Architecture, Urbanism, the Welfare State and After' iç Jakob Nilsson ve Sven-Olov Wallenstein (edr), Foucault, Biopolitics, and Governmentality, (Södertörn University 2013) 115. Ayrıca bakınız Foucault, Hapishanenin Doğuşu (n 14) 12-24; Szasz, Deliliğin İmalatı (n 19) 319. Toplumun, ahlakın, sağduyunun düzenine yönelik rahatsızlık sinyalleri veren ancak birbirinden farklı birçok kişinin kapatıldığı büyük 1slah evleri olarak tabir edilmektedir. Bakınız Foucault, Akıl Hastalığı ve Psikoloji (n 19) 86-87.

135 Serseriliğin herhangi bir patoloji, bağımlılık bulunmaksızın toplumsal tehlike sebebi olarak algılanmasının temelinde sosyokültürel normlara göre marjinal görülen kişilere karşı geliştirilen önyargıların etkili olduğu ileri sürülebilir. Bakınız Foucault, Akı1 Hastalığı ve Psikoloji (n 19) 79. Hukuksal açıdan böylesine muğlak bir kavram çerçevesinde özgürlüğü kısıtlama sebebinin öngörülmesi kabul edilebilir değildir.
} 
amacıyla birlikte yorumlandığında tedavi amacıyla özgürlüğü kısıtlanan kişinin ölçülülük kriterine uygun olduğu sürece tedaviye zorlanması mümkün sayılabilir. Bu noktada dikkat edilmelidir ki ilgili kişi henüz suç işlemiş olmayıp yalnızca toplum için tehlike oluşturduğu varsayıldığından zorlayıcı tedbirlere gerçekten zorunluluk halinde ve bu amaçla sınırlı olarak başvurulması ölçülü sayılabilir. ${ }^{136}$

\section{Kamu Sağlığının Korunması Amacına Yönelik Tıbbi Müdahaleler}

\section{Zorunlu Aşılama}

Bağışıklama ve dolayısıyla bulaşıcı hastalıkların yayılmasını önleme amacıyla hasta olmayan ancak hastalığa yakalanma riskini doğrudan veya dolaylı olarak taşıyan kişiler için kamu sağlığının korunabilmesi amacıyla zorunlu aşılama tedbirine başvurulması mümkündür ancak İnsan Hakları ve Biyotıp Sözleşmesi ile Anayasa hükümleri gereğince bu zorunluluğun kanuna dayandırılması, kanun hükümleriyle belirli ve somut hale getirilerek öngörülebilir k1lınması gerekmektedir. ${ }^{137}$ Halk sağlığının korunması amacıyla zorunlu aşlama öngören düzenlemeler Türk hukukunda 24.04.1930 tarih ve 1593 sayılı Umumi Hıfzıssıhha Kanunu'nda sevk edilmiştir. Umumi Hıfzıssıhha Kanunu'nun 72. maddesinin birinci fikrasının ikinci bendine göre söz konusu yasanın 57. maddesinde sayılan hastalıkların ${ }^{138}$ ortaya çıkması halinde hastalara veya hastalığa yakalanma riskine maruz kalanlara aşı ve serum uygulanması yolunda tedbir alınması mümkündür. Söz konusu hastalıklar için zorunlu aşı uygulanması için salgın meydana gelmesi aranmamaktadır. Öte yandan yasanın 64. maddesine göre 57. maddede sayllmayan herhangi bir hastalık salgına dönüşürse ve salgın tehlikesi baş gösterirse yasanın 72. maddesinde belirtilen zorunlu aşılama tedbirine başvurma hususunda Sağlık Bakanlığı yetkili sayılmıştır. Dolayısıyla bugün için pandemi niteliğinde bir salgına dönüşen COVID-19 açısından aşı geliştirilecek olursa yasanın verdiği yetki doğrultusunda Sağlık Bakanlığı'nın aktif bağışıklık geçirmemiş kişiler için aşı zorunluluğu öngören bir yönetmelik kabul etmesi mümkün olacaktır. ${ }^{139}$

Salgın tehlikesinden bağımsız olarak Umumi Hıfzıssıhha Kanunu'nun 88. maddesi ve devamındaki maddelerine göre çiçek aşısı olma zorunluluğunun getirildiği görülmektedir. Yasanın 88. maddesinde Türkiye dahilinde her ferdin çiçek aşıs1 ile aşılanmak zorunda olduğu, 90. maddesinde 30 yaşına kadar her kişinin

\footnotetext{
136 Ölçülülük kriterinin gereği olarak zorunluluk koşulu hakkında bakınız Tanör ve Yüzbaşığlu (n 59) 165-166.

137 Bakınız D Çiğdem Sever, 'COVID-19 Günlerinde İdare Hukuku: Salgınla Mücadelede Kolluk Yetkileri Üzerine Bir İnceleme’ (2020) 9(17) Anayasa Hukuku Dergisi 187, 190-194, 211-213; Kasapoğlu Turhan (n 94) 18 vd

138 Kolera, veba (Bübon veya zatürree şekli), lekeli humma, karahumma (hummayi tiroidi) daimi surette basil çıkaran mikrop hamilleri dahi - paratifoit humması veya her nevi gıda maddeleri tesemmümatı, çiçek, difteri (Kuşpalazı) - bütün tevkiatı dahi sari beyin humması (İltihabı sahayai dimağii şevkii müstevli), uyku hastalığı (İltihabı dimağii sari), dizanteri (Basilli ve amipli), lohusa humması (Hummai nifası) ruam, kızıl, şarbon, felci tıfli (İltihabı nuhai kuddamii sincabii haddı tifli), kızamı, cüzam (Miskin), hummai racia ve malta humması

139 Sever (n 137) 205, 213-214.
} 
bu aşıyı beş y1lda bir tekrar ettirmek zorunda olduğu, 89. maddesinde Türkiye'de doğan her çocuğun doğumunu izleyen ilk dört ay içinde aşılanacağı, bu hususta anne babanın veya çocuğa bakmakla sorumlu olan kişi veya kurum müdürlerinin sorumlu olduğu belirtilmektedir. Bu hususta son olarak UHK madde 90'da çiçek hastalığının salgına yol açması halinde sağlık memurlarınca gerekli görülecek herkese çiçek aşısı uygulanmasının zorunlu olduğu ifade edilmektedir. Fakat dünyada ve Türkiye'de çiçek hastalığının geçmişte kalması sebebiyle Türkiye'de 1980 yılında çiçek aşısı üretiminin durdurulduğu ve çiçek aşısının rutin uygulamasına da böylece son verildiği bilinmektedir. ${ }^{140}$ Umumi Hifzıssıhha Kanunu'nda son olarak kuduz olduğundan şüphelenilen hayvanlar tarafından ısırılmış olanların en yakın kuduz tedavi kurumuna başvurmaları ve dolayısıyla gerekli müdahalede bulunulmasına izin vermeleri zorunludur. Bu bağlamda uygulamada kuduz aşısı yapılarak hastalığın insana bulaşmasına engel olunmaktadır. Ancak kuduz aşısının Türkiye'deki üretimine 1996 yılında son verilmiş olup ihtiyaç halinde yurtdışından tedarik edilmektedir. ${ }^{141}$

Umumi Hıfzıssıhha Kanunu'nda belirtilmemekle birlikte günümüzde görülme riski bulunan pek çok hastalığa karşı koruyucu önlem olarak bebeklik ve çocukluk döneminde bağışıklama uygulaması kapsamında çeşitli aşılar temin edilmekte ve aile hekimliklerinde ücretsiz olarak uygulanmaktadır. Bununla birlikte söz konusu hastalıklar günümüzde salgın niteliğinde görülmediği için UHK çerçevesinde zorunlu olarak uygulanmasının yasal bir temeli bulunmamaktadır. ${ }^{142} \mathrm{Bu}$ sebeple aşının uygulanmasının aksatılması veya özellikle aşılamanın reddedilmesi halinde yalnızca aşı olmayan çocuğun sağlı̆ğ zarar görmekle kalmamakta, aynı zamanda toplum sağlığı da açıkça zarar tehdidine maruz kalmaktadır. Gerçekten de aşı karşıtllğııın yaygınlaştığı ülkelerde aşılama ile önüne geçilmiş olan bazı hastalıkların yeniden baş gösterdiği ve yayıldığ tespit edilmiştir. ${ }^{143} \mathrm{Bu}$ sebepledir ki hem ayırt etme gücü henüz bulunmayan çocukların sağlı̆̆ının hem de kamu sağlığının korunabilmesi için günümüzde aşılamanın gerekli olduğu hastalıklar için zorunlu aşı uygulaması için yasal düzenleme yapılması, bir gerekliliğin ötesinde zorunluluktur.

\section{Zorunlu Tedavi}

Umumi Hifzıssıhha Kanunu'nun 72. maddesinin birinci fikrasının ikinci bendine göre söz konusu yasanın 57. maddesinde sayılan hastalıkların ortaya çıkması halinde hastaların tedavi edilmesi konusunda tedbir alınması mümkündür. Bunun yanında

\footnotetext{
140 'Türkiye'de Aşının Tarihçesi', TC Sağlık Bakanlığı Aşı Portalı <https://asi.saglik.gov.tr/genel-bilgiler/33a $\%$ C5\%9F\%C4\%B1n\%C4\%B1n-tarih\%C3\%A7esi.html> Erişim Tarihi 2 Haziran 2020.

$141<$ https://asi.saglik.gov.tr/genel-bilgiler/33-a\%C5\%9F\%C4\%B1n\%C4\%B1n-tarih\%C3\%A7esi.html> Erişim Tarihi 2 Haziran 2020.

${ }^{142}$ Farklı görüş için bakınız Güngör (n 83) 398-399. Kaya Kızılırmak, UHK madde 88 hükmünün objektif zamana uygun yorum yöntemiyle bugün salgın tehlikesi meydana getiren hastalıklar yönünden uygulanmasının değerlendirilebileceğini belirtmektedir. Bakınız Kaya Kızılırmak (n 77) 457-458.

143 Belek (n 94).
} 
yasanın 101. maddesine göre Sağlık Bakanlığı tarafindan oluşturulan trahomla mücadele heyetleri trahoma müptela olduğu anlaşılan hastaları tedavi amacıyla kurumlara zorla getirmeye ve gerekli tedaviyi uygulamaya yetkilidir.

Ayrıca UHK madde 103 gereğince bedenin hangi kısmında ve ne şekilde tezahür ederse etsin frengi, belsoğukluğu, yumuşak şankr hastalıklarına müptela olan her kişi kendini Türkiye'de tıbbı uygulamaya yetkili bir tabibe tedavi ettirmeye mecbur olduğu gibi UHK madde 119 gereğince bulaşıcı şekilde verem hastalı̆̆ına yakalanan hastaları hastane veya başka bir kurumda tecrit ederek tedavi etmeye Sağlık Bakanlığı yetkili sayılmış durumdadır. Yukarıdaki başlıkta da açıklandığı gibi kuduz olan veya olduğundan şüphelenilen bir hayvan tarafından 1sırılmış kişinin hastalıktan korunmak veya hastalandığı takdirde tedavi için kuruma başvurmaya ve gerekli müdahalelerde bulunulmasina izin vermek zorundadır.

Umumi Hifzıssıhha Kanunu'nun 64. maddesi gereğince 57. maddede sayılmayan herhangi bir hastalı̆̆ın salgına yol açması halinde bu hastalığa yakalanan kişiler için tedavi zorunluluğu getirilmesine Sağlık Bakanlığı yetkili sayılmaktadır. ${ }^{144}$ Dolayısıyla günümüzde COVID-19 hastalığına yakalanan kişiler için tedavi zorunluluğu getirilmesi mümkündür ancak bunun UHK gereğince İçişleri Bakanlığı genelgesiyle veya başka şekilde değil Sağlı Bakanlığı'nca usulüne uygun olarak yapılacak düzenleyici işlemle öngörülmesi gereklidir. ${ }^{145}$

Öte yandan Umumi Hıfzıssıhha Kanunu'nun çeşitli hükümlerinde salgına yol açmış olmasa bile tedavi zorunluluğu öngörülen hastalıklar dışında bir bulaşıcı hastalı̆̆a Türkiye'de bir kişinin yakalanmış olması halinde, ilgili kişi kendi onamıyla tedavi olmadığ amaciyla özgürlük kısıtlamasına başvurulabilecektir. Türk Medeni Kanunu'nun 432. maddesine göre vesayet makamı tarafından ilgili kişinin tedavi amacıyla kuruma yerleştirilmesine ve tedavi edilmesine karar verilebilmektedir. Belirtmek gerekir ki TMK 432 çerçevesinde zorunlu tedavi amacıyla önlemler bulaşıcı hastalıklar dışındaki sebeplere bakıldığında kişinin ayırt etme gücünü geçici veya sürekli olarak ortadan kaldıran, davranışlarını kontrol etmekle güçlük çekmesine yol açan sebepler olduğu görülmektedir. Kişisel korunmayı sağlamak amacıyla vesayet hükümleri içinde yer alan bu düzenlemede bulaşıcı hastalıklara dair özgürlüğü kısıtlayıcı tedbirin yer alması sistematik açıdan isabetli değildir.

Zorunlu tedavi kapsamında belirtilen düzenlemeler zihinsel değil organik patolojilerin tedavisine yönelik olması bakımından genellikle tartışmalara yol açmamaktadır. Ancak bu bağlamda önemli olan söz konusu hastalıkların başka

\footnotetext{
144 Umumi Hıfzıssıhha Kanunu uyarınca alınabilecek önlemler hakkında bilgi ve değerlendirmeler için bakınız Sever (n 137) $202 \mathrm{vd}$

145 Bakınız Sever (n 137) 203.
} 
kişilere özellikle kamusal alanda bulaşma riskinin yüksekliğidir. Eğer her bulaşıcı hastalık için zorunlu tedavi getirilecek olursa onam hakkına ölçüsüz bir sınırlandırma getirilmiş olacağı belirtilmelidir. Dolayısıyla salt korunmasız cinsel ilişki yoluyla veya kan yoluyla bulaşabilen HIV ya da Hepatit için tedavi zorunluluğu ölçüsüz bir sınırlandırma sayılabilir. Söz konusu virüsleri taşıyan kişiler için hastalığın tedavisi zorlu ve kronik olabilmektedir, üstelik hastalık kontrol altına alınsa bile kişiler virüsü taşımaya devam edebilmektedir. Oysaki frengi, belsoğukluğu gibi hastalıklarda virüs değil bakteri söz konusu olduğu için tedavi kolay ve görece kısa sürelidir. ${ }^{146}$ COVID-19 virüsü de solunum yoluyla kolaylıkla bulaşabilmesi sebebiyle ${ }^{147}$ salgın sona erdikten sonra dahi tedavi zorunluluğu getirilmesi makul görülebilecek bir bulaşıcı hastalık etkenidir.

\section{Deneyler}

İnsanlar ve hayvanlar üzerinde tıbbi müdahalede bulunmak suretiyle deney yapılmasının, bir başka ifadeyle biyoloji ve tıbbın deneysel amaçla canlılar üzerinde kullanılmasının belirli koşulları bulunmaktadır. Bu koşullar yönünden özellikle canlılara mümkün olduğu kadar acı çektirilmemesi, gereksiz acı ve ağrı verecek yöntemlerden kaçınılması, onur kırıcı, aşağılayıcı bir muamelede bulunulmaması önem arz etmektedir. ${ }^{148}$ Hayvanlar üzerinde yapılacak deneylerde uyulmas1 gereken ilkeler Çevre ve Orman Bakanlığı tarafindan kabul edilen ve 06.07.2006 tarihli Resmi Gazete'de yayımlanan Hayvan Deneyleri Etik Kurullarının Çalışma Usul ve Esaslarına Dair Yönetmelik' in “Yerel Etik Kurullarının Çalışma İlkeleri” başlıklı 14. maddesinde açıklanmaktadır. ${ }^{149}$ Hayvanlardan farklı olarak insanlar kendi iradesini oluşturabilen ve bunu ifade edebilen varlıklar olarak özerklik hakkının süjesi kabul edildiği içindir ki insanlar üzerinde deney yapılabilmesinin en önemli koşulu üzerinde deney yapılacak kişinin buna özgür iradesiyle deneyden önce onam vermesidir. ${ }^{150}$ Türk Medeni Kanunu'nun 23. maddesinin üçüncü fikrasına göre insan kökenli biyolojik maddelerin alınması, aşılanması ve nakli yazılı onam üzerine mümkündür ve kişi bunu yerine getirmeyi üstlense bile vazgeçebilir. Hasta Hakları Yönetmeliği’nin 32. maddesine göre de hiç kimse onamı olmaksızın eğitim, tecrübe veya araştırma amacıyla tıbbi müdahale konusu yapılamaz. Söz konusu Yönetmeliğin devam eden maddelerinde bu onamın alınma usulü hakkında hükümler öngörülmektedir. Deneyin tümüyle gönüllülük esasına dayalı olarak ve her tür öngörülebilen riski ilgili tarafından kabul edilerek gerçekleştirilmesi insan haklarının gereğidir. Bu hususta

\footnotetext{
$146<$ https://www.sagligim.gov.tr/bulasici-hastaliklar/liste/688-gonore-bel-so\%C4\%9Fuklu\%C4\%9Fu-nedir.html $>$; $<$ https:// sagligim.gov.tr/bulasici-hastaliklar/liste/679-sifiliz-frengi-nedir.html > Erişim Tarihi 4 Temmuz 2020. Virüs söz konusu olduğunda aşı ve serumlar tedavide daha önemli hale gelmektedir. Bakınız Sever (n 137) 210-211.

$147<$ https://sagligim.gov.tr/yeni-2019-n-cov-virus-korona-virus.html > Erişim Tarihi 4 Temmuz 2020.

148 Hayvan onuru hakkında bakınız Gürbüz (n 13) 95-97.

149 Hayvanlar üzerindeki deneyler hakkında hukuksal bilgi için bakınız Dumancı (n 18) 29-30.

150 Bakınız Dumanc1 (n 18) 42 vd
} 
üstün kamu yararı olsa dahi onam hakkının hiçbir istisnası olamaz, bir başka deyişle ilgilinin istemediği, onay vermediği bir deney kamunun yararına olsa bile insan onurunun korunması gereği yapılamayacaktır. ${ }^{151}$ İnsanlar üzerinde hukuka uygun olarak deney yapılmasının koşulları Türk Ceza Kanunu'nun 90. maddesinin ikinci, üçüncü ve dördüncü fikralarında öngörülmektedir.

İnsan üzerinde deneylerle ilgili düzenlemeler salt bilimsel araştırma amaçlı deneylere ilişkin olanlar ile tedavi amaçlı deneylere (denemelere) ilişkin olanlar şeklinde ikiye ayrılabilir. ${ }^{152}$ Salt bilimsel araştırma amaçlı deneylerde üzerinde deney yapılacak kişinin kendisinin hiçbir yararı olmadığ 1 için tedavi amaçlı deneye göre daha özel, nitelikli koşullar aranmaktadır. İlgilinin kendisine doğrudan yarar sağlayacak deneyler yönünden üstün kamu yararından söz edilemeyeceği için bu başlık altında deneysel tedaviye değinilmeyecektir. Yasanın 90. maddesinin ikinci fikrasına göre deneyle ilgili olarak yetkili kurul veya makamlardan izin alınması, öncelikle insan dışı deney ortamında yapılmış olması, insan dışı deney ortamındaki deneyler sonucu ulaşılan verilerin hedefe ulaşmak açısından insanlar üzerinde yapılmasını gerekli kılmasi ${ }^{153}$, deneyin insan sağlığ bırakmaması, deney sırasında kişiye insan onuruyla bağdaşmayacak ölçüde acı verici yöntemlerin uygulanmaması, deneyle varılmak istenen amacın getirdiği külfetlere ve sağlık üzerindeki tehlikeye göre daha ağır basması ve hiçbir menfaat teminine bağlı olmaksızın ${ }^{154}$ yani koşulsuz bir şekilde deney için aydınlatılmış onam alınması gereklidir.

Çocuklar üzerinde bilimsel araştırma amaçlı deney yapılabilmesi için ise Türk Ceza Kanunu'nun 90. maddesinin üçüncü fikrasına göre yukarıdaki koşullara ek olarak deneyin hedefleri açısından çocuklar üzerinde de yapılmasının gerekli olması, onam açıklama yeteneğine sahip (ayırt etme gücüne sahip) çocuğun kendi onamı yanında anne babasının veya vasisinin yazılı onamının alınması ve yetkili kurullarda çocuk sağlığı ve hastalıkları uzmanının bulunması gereklidir. ${ }^{155} \mathrm{Bu}$ noktada yalnızca onam açıklama yeteneğine sahip çocuğun onamının aranmasıyla yetinilmesi isabetli değildir. İster çocuk ister ergin olsun bir kişinin ayırt etme gücünden yoksun olması durumunda

$\overline{151}$ Yüksel (n 50) 99-100; Ertem (n 12) 530. Metin'in haklı olarak belirttiği üzere ekonomik verimlilik veya bilimsel ilerleme gibi gerekçeler insanın araçsallaştırılmasını meşrulaştıramaz. Bakınız Metin (n 13) 365.

152 İnsan üzerinde deney ve deneme hakkında ayrıntılı bilgi ve değerlendirmeler için bakınız Barış Erman, 'İnsan Üzerinde Deney ve Deneme Suçları' (2016) 13(2) Yeditepe Üniversitesi Hukuk Fakültesi Dergisi 1 vd; Metin (n 13) 405 vd; Yüksel (n 50) 3-6; Dumanc1 (n 18) 30 vd, 100-102.

153 Benzer şekilde İnsan Hakları ve Biyotıp Sözleşmesi'nin 16. maddesinin ilk bendine göre insanlar üzerinde yapılacak araştırmalarla karşılaştırılabilir etkinlikte başka bir araştırma seçeneğinin bulunmaması koşulu aranmaktadır.

154 Menfaat temini olmaması koşulunun uygulamadaki gerçeklerle bağdaşmaması sebebiyle bu yasağın kanundan çıkarılması gerektiği ileri sürülmektedir. Bakınız Metin (n 13) 408. Karşılaştırınız Dumancı (n 18) 48-49.

155 Çocuklar üzerinde deney hakkında bakınız Yüksel (n 50) 78-80. Hasta Hakları Yönetmeliği'ne göre küçükler ve ayırt etme gücü olmayanlar üzerinde sırf bilimsel amaçlı deneyler yapılamayacağı belirtilse de bilim özgürlüğü temel hak ve özgürlük olduğu içindir ki getirilecek kısıtlamanın yönetmelikle değil kanunla gerçekleştirilmesi gerekir. Eğer İnsan Hakları ve Biyotıp Sözleşmesi deney yapılmasının önüne geçmiş olsaydı TCK hükmü değil Sözleşme hükmü üstün tutulurdu. Karşılaştırınız Dumancı (n 18) 50-51. 
bile kendisine doğrudan yarar sağlamayacak bir deney için mutlaka kendisine sorulmalıdır. Bu husus dolaylı olarak İnsan Hakları ve Biyotıp Sözleşmesi’nin 17. maddesinin ilk fikrasının son bendinde "ilgili kişinin itirazda bulunmaması" şeklinde açıklanmaktadır. Nitekim İlaç ve Biyolojik Ürünlerin Klinik Araştırmaları Hakkında Yönetmelik ${ }^{156}$ madde 6/1/c'de -ayırt etme gücü olup olmadığına bakılmaksızınçocuğun katılmayı reddetmesi veya herhangi bir aşamada çekilmek istemesi halinde çocuğun araştırmadan çıkarılacağı belirtilmiştir. ${ }^{157}$ Ek olarak ayırt etme gücünden yoksun kişilerin menfaatinin korunabilmesi için kendisine doğrudan yarar sağlamayacak deneylerin yapılabilmesi için araştırmanın aynı hastalık veya aynı yaş grubunda olan diğer kişilere fayda sağlaması amacıyla, yani üstün kamu yararı uğruna başvurulması ve ilgili için yalnızca asgari düzeyde tehlike ve külfet getirmesi gereklidir. İnsan Hakları ve Biyotıp Sözleşmesi hükümlerinin insan hakları açısından bu konuda daha iyi bir koruma sağlaması sebebiyle Anayasa madde 90 gereği TCK hükümlerine göre üstün tutulması gerekmektedir. ${ }^{158}$ Öte yandan Sözleşme ve TCK hükümlerine karşın çocuğa hiçbir yarar sağlamayacak bir deneye yasal temsilcisinin onam vermeye yetkili olmadığını, yasal temsil yetkisinin ehliyetsiz kişilerin korunması amacıyla sınırlı tanındığını belirtmek gerekir. Dolayısıyla onam ehliyeti bulunmayan kişiler üzerinde onlara hiçbir yarar sağlamayacak bir deney yapılmasına yasal temsilci tarafından gösterilecek onamın meşru olduğu ileri sürülemeyeceği için bu deneylerin yapılması hukuka uygun olmayacaktır. ${ }^{159}$

\section{Sonuç}

Kişilik değerlerinin birbiriyle bağlantılı bütün olduğu ve hatta bu nedenle kişilik hakları tabiri yerine kişilik hakkı tabirinin kullanıldığı dikkate alındığında kişinin bedeni, zihinsel varlığg ve sosyal bütünlüğü birbiriyle etkileşim halindedir ve bu nedenle bunlardan birine yönelen müdahale diğerlerini de etkilemektedir. Aynı şekilde fizyolojik bütünlüğe yönelik bir tıbbi müdahalenin kişinin psikososyal varlığ ve bütünlüğü üzerinde önemli etkiler meydana getirdiği açıktır. Kişilik değerlerine yönelik bir müdahaleyi tıbbi müdahale kılan özellik, müdahalenin amacı veya kim tarafından yerine getirildiği değil, yöntemi ve kullanılan bilginin niteliğidir. Müdahaleye yetkilendirilmiş bir kişinin değil de yetkisiz bir kişinin bu bilgileri az çok kullanarak girişimde bulunması halinde de tıbbi müdahale vardır ancak hukuka aykırıdır. Müdahalenin özel hukuka uygunluk koşullarına tabi tutulmasının nedeni biyoloji ve tıbbın elde ettiği özel, nitelikli bilginin ve bu bilgi sayesinde üretilen

\footnotetext{
156 Yönetmeliğin 8. Maddesinde ayırt etme gücü nedeniyle kısıtlanıp kısıtlanmadığına bakılmaksızın çocuklarla aynı düzenlemeye tabi tutulması İnsan Hakları ve Biyotıp Sözleşmesindeki muvafakat yeteneği olmayan kişiler kavramının doğru anlaşılmaması ile açıklanabilir. Muvafakat yeteneği olmayan kişiler zihinsel açıdan muhakeme kabiliyeti olmayan yani ayırt etme gücünden yoksun kişiler olarak anlaşılabilir.

157 RG 13.04.2013.

158 Sözleșmenin organ nakli ile ilgili hükümlerine çekince koyulurken bilimsel araștırmayla ilgili hükümlerine çekince koyulmamasına dikkat çekilmektedir. Bakınız Özbilen (n 32) 282-284.

159 Erman (n 152) 33. Ayrıca bakınız Dumancı (n 18) 55.
} 
teknolojinin kullanılması olduğuna göre müdahaleyi tıbbi müdahale kılan unsur, müdahalede kullanılan veya kullanılması amaçlanan bilginin nitelikliliğidir. Tıbbi bilgiyi kullanarak müdahalede bulunanın karşısındaki kişi genellikle bu bilgiden yoksun olduğu için zayıf konumdadır, hasta veya danışan ile kurulan ilişkinin sömürüye açık durumda olması da bu asimetriye dayanmaktadır. Söz konusu nitelikli bilgi yalnız hiyerarşik ilişki kurulmasına yol açmakla kalmayıp iktidar sahibi tarafindan düzenin devamı ve bireylerin bu düzene itaat etmeleri amacıyla farklı gerekçelerle araçsallaştırılmakta ve tıp bedenler üzerinde sosyal kontrol aracına dönüştürülmektedir. Bu açıdan bakıldığında çalışmada biyopolitika bakımından tıbbi müdahalelerde yararlılık kaygısı üzerinde sosyal kontrol güdüsünün etkileri üzerinde durulmuştur.

Onam yerine geçen hukuka uygunluk sebeplerinin biyopolitika bağlamındaki etkilerini değerlendirmeden önce onamın hukuka uygunluğunun koşulları gözden geçirildiğinde müdahalenin sağlık için gerekli olması veya sağlık refahı yönünden yararlı olması aranmamalı, buna karşı1lı müdahalenin meşru bir amaca yönelik olması yeterli görülmelidir. Sağlık için gerekli veya yararlı olduğu ileri sürüldüğünde sübjektif değerlendirmeler doğrultusunda bireylerin kendi ilişkilerini, bedenini, geleceğini tayin etme hakkına gerekçesiz bir sınırlandırma getirilebileceği, bir başka deyişle belirli bir yaşam tarzının dayatılacağı anlaşılmaktadır. Üstelik neyin hastalık olduğu ve dolayısıyla hangi durumda müdahalenin gerekli olduğu zaman içinde değişebilen normlar olup özellikle zihinsel tıp yönünden tıbbın son derece politik olduğu belirtilmelidir. Bunlardan uzak biçimde bireylerin özerkliğine saygıl1 ve araçsallaşmayan tıbbi yaklaşım için kişilerin kendileri için neyin yararlı olduğuna karar vermelerine izin verilmelidir. Bu noktada müdahalenin açıkça zararlı ve küçük düşürücü, onur kırıcı olup olmadığına dikkat edilmeli ve böylece meşru olup olmadığı değerlendirilmelidir. Bu yaklaşım kişilere hangi durumda tıbbi müdahalenin dayatılabileceği, bir başka ifadeyle zorla tıbbi müdahalede bulunabileceği konusunda gerekçe ve ipucu vermektedir.

Onam yerine geçen hukuka uygunluk sebebi olarak üstün yarar kavramına dayanıldığında birbiriyle çatışan menfaatler arasında kurulması gereken denge açısından beklenen yararlar ile sakıncaların karşılaştırılması ve her müdahale için verilecek kararda ölçülülük kriterine dayanılması gerekmektedir. Çalışmada ele alınan çatışma halleri arasında yasal temsilciyle düşülen çatışmadaki karar verme ölçütlerini diğerlerinden ayırmak gerekir. Zira yasal temsilci kendi bedeniyle ilgili değil başkasının bedeniyle ilgili kararlar verdiği için keyfi olarak değerlendirme ve karar verme yetkisi yoktur. Kendisine tanınan yetkilerin tek amacı ehliyetsizin menfaatlerini korumak ve bu doğrultuda onun için gerekli müdahalelere izin vermek, gerekli olmayan müdahalelerin yapılmasının önünde durmaktır. Bu noktada kendisine müdahalede bulunulacak ehliyetsiz kişi direnmediği, reddetmediği, 
dolayısıyla çatışmadığı takdirde onun yasal temsilcisinin görüşü değil, ehliyetsiz kişinin menfaatleri belirleyici olur. Bu yönden bebeklik dönemi aşıları, yetişkinler üzerinde uygulanması olası zorunlu aşılardan ayırt edilerek tartışılmıştır. Buna karşılık kendisine müdahalede bulunulan ehliyetli kişinin kendisiyle çatışmaya düşülmesi halinde müdahalede bulunulmadığında meydana gelebilecek sonuçların devlet iktidarına $\mathrm{m}$ başkalarının temel hak ve özgürlüklerine mi zarar vereceği tartışılmalıdır. Soyut bir devlet iktidarını koruma gerekçesi çoğu kez kişileri disiplin altına almak ve onları itaatkâr kılmak dışında bir menfaate hizmet etmeyecektir.

Müdahalede bulunulması halinde sağlanacak fayda özerkliğin ihlali halinde kişi için yarattığı külfetler karşısında dikkate alınmayacak kadar önemsiz olduğu takdirde müdahale yasaya dayansa bile Anayasa gereği ölçülülük kriterine uygun düşmeyeceği için bundan kaçınılmalıdır. Dolayısıyla özellikle belirtilmesi gereken husus üstün yarar gerekçesiyle onam hakkına kısıtlama olarak yasada öngörülen her zorla veya zorunlu müdahale için somut olayda kişinin buna zorlanmasının uygun olup olmadığ değerlendirilmek zorundadır. Kanaatimizce değişiklik yapılması gereken hususlardan biri cinsel şiddet mağduru için zorla muayene öngören düzenlemedir, zira mağdurun muayeneye zorlanması ikincil travma yaratacak ve şiddetin sürmesine yol açacaktır. Öte yandan biyolojik madde bağışı ve salt bilimsel amaçlı deneylere ilişkin olarak onam alınmaksızın müdahalede bulunulmamasının hiçbir istisnasının olmayacağı vurgulanmalıdır, zira kişinin içinde bulunduğu durum toplum için külfet yaratmadığı halde ondan fedakârlıkta bulunmasını beklemenin ahlaki bir gerekçesi yoktur.

\footnotetext{
Hakem Değerlendirmesi: Dış bağımsız.

Çıkar Çatışması: Yazar çıkar çatışması bildirmemiştir.

Finansal Destek: Yazar bu çalışma için finansal destek almadığını beyan etmiştir.

Teșekkür: Biyopsikososyal yaklaşımın önemi konusunda bana ilham veren fizyoloji uzmanı bir hekim olan Prof. Dr. Şebnem Gülen'e teşekkür ederim.

Peer-review: Externally peer-reviewed.

Conflict of Interest: The author has no conflict of interest to declare.

Grant Support: The author declared that this study has received no financial support.

Acknowledgements: I would like to thanks Prof. Dr. Şebnem Gülen who inspired me about the importance of the biopsychosocial approac.
} 


\section{Bibliyografya/Bibliography}

Akbıyık C ve Aydın GS, 'Hukuk Muhakemeleri Kanunu M.292 Uyarınca Kişilerden Soybağı Tespiti Amacıyla Zor Kullanılarak Kan veya Doku Alınmasının Kişilik Hakkını İhlal Edip Etmediği Sorunu’ (2014) 13(1) İstanbul Kültür Üniversitesi Hukuk Fakültesi Dergisi 7-31.

Aksoy Dursun S, 'Soybağının Belirlenmesi Bakımından MK m. 284 ve HMK m. 292'nin Değerlendirilmesi’ (2012) 8(95-96) Kazanc1 Hakemli Hukuk Dergisi 109-124.

Aksoy İpekcioğlu P, 'Vücuttan Örnek Alma İşleminin Hukuki Niteliği ve Anayasaya Uygunluğu' (2013) 19(2) Marmara Üniversitesi Hukuk Fakültesi Hukuk Araştırmaları Dergisi (Prof Dr Nur Centel'e Armağan) 1157-1175.

Akyüz E, Çocuk Hukuku Çocukların Hakları ve Korunması (3. Bası, Pegem 2013).

Badur E, Tıbbi Müdahaleye Rızanın Özellik Gösterdiği Haller (Seçkin 2017).

Belek İ, 'İngiltere’de Kızamık Salgını ve Aşı Karşıtlığı' (Sol Haber Portalı, 12 Ocak 2018) <https:// haber.sol.org.tr/dunya/ingilterede-kizamik-salgini-ve-asi-karsitligi-224706> Erişim Tarihi 27 Haziran 2020.

Çalışkan M, Madde Bağımlılığının Biyo-Psiko-Sosyal ve Hukuksal Analizi (Beta 2018).

Demirdoğan S ve Solmaz M, 'Psikiyatride 'Zorunlu Yatışlar” (2019) 32(2) Adli Tıp Dergisi 84-90.

Dumancı G, İnsan Konulu Klinik Araştırmalar ve Hukuki Boyutu (Legal 2020).

Dural M ve Öğ̈̈z, T, Türk Özel Hukuku Cilt II Kişiler Hukuku (20. Bas1, Filiz 2019).

Dural M, Öğüz T ve Gümüş MA, Türk Özel Hukuku Cilt III Aile Hukuku (13. Bas1, Filiz 2018).

Elçin Grassinger G, Türk Medeni Kanununda Yer Alan Velayet Hükümleri Kapsamında Küçüğün Kişi Varlı̆̆ının Korunması İçin Alınacak Tedbirler (On İki Levha 2009).

Erman B, ‘İnsan Üzerinde Deney ve Deneme Suçları’ (2016) 13(2) Yeditepe Üniversitesi Hukuk Fakültesi Dergisi 1-44.

Ertem B, Tip Ceza Hukukunda Kendi Geleceğini Tayin Hakkının Yansıması Olarak Rıza ve Sinırları (Yayımlanmamış Doktora Tezi, Ankara Üniversitesi Sosyal Bilimler Enstitüsü, 2015).

Foucault M, Hapishanenin Doğuşu Çev Mehmet Ali Kılıçbay (8. Bas1, İmge 2019).

Foucault M, Biyopolitikanın Doğuşu Collége de France Dersleri 1978-1979 Çev Alican Tayla (İstanbul Bilgi Üniversitesi 2015).

Foucault M, Akıl Hastalı̆̆ ve Psikoloji Çev Emre Bayoğlu (5. Bası, Ayrıntı 2019).

Foucault M, Akıl ve Akıl Bozukluğu Klasik Çağda Deliliğin Tarihi Çev Mehmet Ali Kılıçbay (2. Bas1, İmge 1995).

Froggett L ve Richards B, 'Exploring the Bio-Psycho-Social' (2002) 5(3) The European Journal of Psychotherapy, Counselling \& Health 321-326.

Gözler K, Türk Anayasa Hukuku Dersleri (25. Bas1, Ekin 2020).

Güngör HA, 'Anayasa Mahkemesi'nin Topuk Kanı Testi ve Zorunlu Aşılama Uygulamaları Hakkındaki Kararlarına İlişkin Kısa Bir Değerlendirme' (2018) 10(100) Fasikül Hukuk Dergisi 395-400.

Gürbüz N, Biyotıp Hukukunda İnsan Onuru (On İki Levha 2014).

Hakeri H, Tip Hukuku El Kitabı (6. Bası, Seçkin 2013).

Helvacı S, Gerçek Kişiler (2. Bası, Arıkan 2007).

Iş1l Ülman Y, 'Kan ve Kan Ürünlerinin Transfüzyonu ve Tibbi Etik' (1998) 20 Damla Kan Merkezleri ve Transfüzyon Derneği Bülteni 1-4 <http://kmtd.org.tr/damla/20.pdf $>$ Erişim Tarihi 5 Temmuz 2020. 
Kalkan Oğuztürk B, Türk Medeni Hukukunda Biyoetik Sorunlar (Vedat 2011).

Kapani M, Kaтu Hürriyetleri (7. Bas1, Yetkin 1993).

Kara Kılıçarslan S, Kişilik Hakkına Saldırıda Üstün Nitelikte Özel ve Kamusal Yarar (On İki Levha 2015).

Kasapoğlu Turhan M, 'İdari Kolluk Yetkisi Bağlamında Zorunlu Aş1 Uygulaması' (2019) 9(1) Hacettepe Üniversitesi Hukuk Fakültesi Dergisi 1-40.

Kaya Kızılırmak C, 'Velayet Hakkının Kapsamı Çerçevesinde Bebeklik Dönemi Aşı Uygulamalarına Rızanın Esirgenmesi' iç Abuzer Kendigelen ve Saibe Oktay Özdemir (edr), Prof. Dr. Feyzi Necmeddin Feyzioğlu'nun Anısına Armağan (On İki Levha 2020) 449-476.

Kılıçoğlu A, Medeni Hukuk Temel Kavramlar Başlangıç Hükümleri Kişiler Hukuku (Turhan 2016).

Kizılarslan H, Ceza Muhakemesi, Adli Tip, Adli Bilimlerde Vücut Muayenesi ve Örnek Alma (Doktrin ve Uygulama) (Kizılarslan 2007).

Kilkelly U, The right to respect for private and family life, A guide to the implementation of Article 8 of the European Convention on Human Rights (1st, Directorate General of Human Rights, Council of Europe 2003).

Kirkit E, Tıbbi Müdahalenin Hukuka Uygunluğu (Adalet 2016).

Koç A, 'Michel Foucault'nun 'Biyopolitika' Kavramının Teorik Çerçevesi' (2018) 2(2) Uluslararası Kriz ve Siyaset Araştırmaları Dergisi 193-218.

Koçak Süren Ö, 'Organ ve Doku Naklinin Yasal ve Etik Açıdan İncelenmesi’ (2007) 73 TBB Dergisi 174-195.

Lemke T, Biyopolitika Çeviren Utku Özmakas (4. Bası, İletişim 2017).

Marmot M, 'Giriş’ iç Michael Marmot ve Richard G Wilkinson (edr), Sağhlğın Sosyal Belirleyicileri, Çeviri Editörleri İlker Kayı ve Yeşim Yasin (İnsev 2009) 13-17.

Marmot M, Siegrist J ve Theorell T, 'Sağlık ve İş Yerindeki Psiko-Sosyal Ortam' iç Michael Marmot ve Richard G Wilkinson (edr), Sağlığın Sosyal Belirleyicileri, Çeviri Editörleri İlker Kayı ve Yeşim Yasin (İnsev 2009) 119-153.

Metin S, Biyo-Tip Etiği ve Hukuk (2. Bası, Betim 2019).

Nart S, Hekimin İlaç Tedavisinden Doğan Sorumluluğu (2. Bası, Adalet 2020).

Nart S, 'Endikasyon Dışı İlaç Tedavisinde Hekimin ve İlaç Üreticisinin Hukuki Sorumluluğu'. (2017) 19 (Özel Sayı) DEÜHFD (Prof. Dr. Şeref Ertaş'a Armağan) 729-791.

Oğuzman K, Seliçi Ö ve Oktay-Özdemir S, Kişiler Hukuku (Gerçek ve Tüzel Kişiler) (19. Bas1, Filiz 2020)

Orenstein GA ve Lewis L, 'Eriksons Stages of Psychosocial Development' (StatPearls, 9 March 2020) Treasure Island (FL): StatPearls Publishing <https://www.ncbi.nlm.nih.gov/books/ NBK556096/> Erişim Tarihi 9 Haziran 2020.

Özbilen AB, Insan Kökenli Biyolojik Maddelere İlişskin Hukuki İşlemler (Vedat 2011).

Özbudun E, Türk Anayasa Hukuku (7. Bas1, Yetkin 2002).

Özmakas U, Biyopolitika: İktidar ve Direniş Foucault, Agamben, Hardt-Negri (2. Bas1, İletişim 2019).

Öztan B, Aile Hukuku (6. Bas1, Turhan 2015).

Rose S ve Robinson C, 'Beyond Essentialist Critiques: The Co-development of Individual and Society within Erik Erikson's Psychosocial Theory of Identity Development' iç SA Barab, KE Hay ve DT Hickey (edr), The International Conference of the Learning Sciences, Indiana University, Proceedings of ICLS 2006, Vol 2 (International Society of the Learning Sciences 2006) 620-626. 
Sağlam M, 'Ekim 2001 Tarihinde Yapılan Anayasa Değişiklikleri Sonrasında, Düzenlendikleri Maddede Hiçbir Sınırlama Nedenine Yer Verilmemiş Olan Temel Hak ve Özgürlüklerin Sınırı Sorunu' (2002) 18(1) Anayasa Yarg1sı Dergisi 233-266.

Serim G, Roma İmparatorluk Döneminde Aile Hukukuna İlişkin Düzenlemeler (Lykeion 2018).

Serozan R, Medeni Hukuk Genel Bölüm Kişiler Hukuku (7. Bas1, Vedat 2017).

Serozan R, Çocuk Hukuku (2. Bası, Vedat 2005).

Sert G, Uluslararası Bildirgeler ve Tıp Etiği Açısından Hasta Hakları (2. Bası, Seçkin 2019).

Sever DÇ, 'COVID-19 Günlerinde İdare Hukuku: Salgınla Mücadelede Kolluk Yetkileri Üzerine Bir İnceleme' (2020) 9(17) Anayasa Hukuku Dergisi 187-238.

Shaw M, Dorling D ve Smith GD, 'Yoksulluk, Toplumsal Dışlanma ve Azınlıklar' iç Michael Marmot ve Richard G Wilkinson (edr), Sağlı̆̆ın Sosyal Belirleyicileri, Çeviri Editörleri İlker Kay1 ve Yeşim Yasin (İnsev 2009) 226-256.

Stanek L, 'Biopolitics of Scale: Architecture, Urbanism, the Welfare State and After' iç Jakob Nilsson ve Sven-Olov Wallenstein (edr), Foucault, Biopolitics, and Governmentality (Södertörn University 2013) 105-122.

Szasz T, Deliliğin İmalatı Çeviren Gözde Genç (Yerdeniz 2007).

Szasz T, Yalanlar Bilimi Psikiyatri Çeviren Nur Küçük (Aylak Kitap 2013).

Şen E ve Bodur FB, 'Devletin Yaşam Hakkını Koruma Zorunluluğu' (2017) 12(132) Terazi Hukuk Dergisi 125-131.

Şenocak Z, 'Küçüğün Tıbbi Müdahaleye Rızası' (2001) 50(4) AÜHFD 65-80.

Tanör B ve Yüzbaşığlu N, 1982 Anayasasına Göre Türk Anayasa Hukuku (19. Bas1, Beta 2019).

Tüzüner Ö, Adli Genetik ve Tıbbi Biyoloji Bilimlerinin Soybağı Hukukuna Etkisi (Filiz 2016).

Yücel Ö, Ayırt Etme Gücünden Yoksun Kişiler Adına Alınan Tıbbi Kararlarda Özerklik Hakkının Korunması ve Hasta Talimatları (Seçkin 2018).

Yüksel H, Kişilik Hakkı İhlali Kapsamında İnsan Üzerinde Yapılan Deneyler ve Hukuki Sonuçları (On İki Levha 2017). 
